OPEN ACCESS

Edited by:

Johann Heider

University of Marburg, Germany

Reviewed by:

Bodo Philipp,

University of Münster, Germany Wael Ahmed Ismail,

Arabian Gulf University, Bahrain

${ }^{*}$ Correspondence:

José L. García

jlgarcia@cib.csic.es

Specialty section

This article was submitted to

Microbial Physiology and Metabolism,

a section of the journal

Frontiers in Microbiology

Received: 28 July 2020 Accepted: 30 October 2020

Published: 07 December 2020

Citation:

Ibero J, Galán B, Rivero-Buceta V and

García JL (2020) Unraveling the $17 \beta$-Estradiol Degradation Pathway in Novosphingobium tardaugens NBRC

16725. Front. Microbiol. 11:588300.

doi: $10.3389 /$ fmicb.2020.588300

\section{Unraveling the 17 $\beta$-Estradiol Degradation Pathway in Novosphingobium tardaugens NBRC 16725}

\author{
Juan Ibero, Beatriz Galán, Virginia Rivero-Buceta and José L. García* \\ Department of Microbial and Plant Biotechnology, Centro de Investigaciones Biológicas Margarita Salas, Consejo Superior \\ de Investigaciones Cientificas, Madrid, Spain
}

We have analyzed the catabolism of estrogens in Novosphingobium tardaugens NBRC 16725, which is able to use endocrine disruptors such as $17 \beta$-estradiol, estrone, and estriol as sole carbon and energy sources. A transcriptomic analysis enabled the identification of a cluster of catabolic genes (edc cluster) organized in two divergent operons that are involved in estrogen degradation. We have developed genetic tools for this estrogen-degrading bacterium, allowing us to delete by site-directed mutagenesis some of the genes of the edc cluster and complement them by using expression plasmids to better characterize their precise role in the estrogen catabolism. Based on these results, a catabolic pathway is proposed. The first enzyme of the pathway (17 $\beta$-hydroxysteroid dehydrogenase) used to transform $17 \beta$-estradiol into estrone is encoded out of the cluster. A CYP450 encoded by the edcA gene performs the second metabolic step, i.e., the 4-hydroxylation of estrone in this strain. The edcB gene encodes a 4-hydroxyestrone-4,5-dioxygenase that opens ring A after 4-hydroxylation. The initial steps of the catabolism of estrogens and cholate proceed through different pathways. However, the degradation of estrogens converges with the degradation of testosterone in the final steps of the lower catabolic pathway used to degrade the common intermediate 3a $\alpha-\mathrm{H}-4 \alpha\left(3^{\prime}\right.$-propanoate)7a- $\beta$-methylhexahydro-1,5-indanedione (HIP). The TonB-dependent receptor protein EdcT appears to be involved in estrogen uptake, being the first time that this kind of proteins has been involved in steroid transport.

Keywords: estrogens, catabolism, bacteria, biodegradation, 17 $\beta$-estradiol, cytochrome P450, E1-hydroxylase, estrogen transport

\section{INTRODUCTION}

Estrogens are C18 steroid hormones synthetized in animals through the elimination of cholesterol side chain and play several physiological roles (Ryan, 1982). The environmental release of estrogens is becoming an increasing public concern because they are important endocrine-disrupting compounds (EDCs) that persistently contaminate surface water, affecting the physiology of aquatic fauna and humans at extremely low concentrations (Teles et al., 2004). Therefore, the occurrence and abundance of estrogens in aquatic environments present a serious risk to public health (Barbosa et al., 2016). In addition, they have been classified by the World Health Organization as group 1 carcinogens (https://monographs.iarc.fr/list-of-classifications-volumes/). Among these 
compounds, the highest estrogenic activity is found in natural hormones like estrone (E1), 17 $\beta$-estradiol (E2), and estriol (E3) and the synthetic estrogen $17 \alpha$-ethinylestradiol (EE2).

The complete mineralization of estrogens to $\mathrm{CO}_{2}$ can be accomplished by a limited number of bacteria, mainly from the phyla Proteobacteria and Actinobacteria (Fujii et al., 2002; Fahrbach et al., 2006; Yu et al., 2007, 2016; Kurisu et al., 2010; Chen et al., 2017; Wang et al., 2019; Li et al., 2020). Although some biotransformation steps have been described in estrogen-degrading strains, the complete degradation pathway still remains unknown (Yu et al., 2013; Wang et al., 2014, 2018, 2019; Chen et al., 2017).

The degradation of $\mathrm{A}$ and $\mathrm{B}$ rings of steroids is achieved through different peripheral pathways depending on the compound, including the 9,10-seco pathway (for aerobic degradation of sterols and androgens), the 2,3-seco pathway (for the anaerobic degradation of sterols and androgens), and the 4,5seco pathway (for aerobic degradation of estrogens) (Wang et al., 2014; Van Hamme et al., 2016; Chen et al., 2017). The anaerobic degradation of estrogens has been described in the Denitratisoma sp. strain DHT3 very recently (Wang et al., 2020). The ability to degrade estrogens anaerobically relies in the retroconversion of estrogens into androgens via a cobalamin-mediated methylation reaction (Wang et al., 2020).

For the aerobic degradation of estrogens, it has been proposed that the E2 degradation pathway (i.e., the 4,5-seco pathway) begins with $17 \beta$-dehydrogenation to render $\mathrm{E} 1$, followed by the oxygenolytic degradation of the aromatic ring $\mathrm{A}$ through the previous 4-hydroxylation and the subsequent meta-cleavage reaction (Chen et al., 2017; Figure 1). The meta-cleavage product of 4-hydroxyestrone is unstable and undergoes a recyclization with ammonia via a non-enzymatic reaction to produce the end product pyridinestrone acid (Chen et al., 2017) and was also detected as a metabolite derived from estrogen degradation in different bacteria (Coombe et al., 1966; Chen et al., 2018; Li et al., 2020). Based on transcriptomic analysis, two gene clusters (clusters I and II) have been identified in Sphingomonas sp. strain $\mathrm{KC} 8$ and proposed to be involved in the degradation of rings $\mathrm{A}$ and $\mathrm{B}$ of E1. A third cluster (III) is proposed for the degradation of $\mathrm{C}$ and $\mathrm{D}$ rings. Cluster I contains $\operatorname{oec} A, \operatorname{oec} B$, and oec $C$ genes, which have been proposed to carry out the initial steps of the degradation pathway. However, only the functions of oec $A$ and oec $C$ gene products, coding a $17 \beta$-hydroxysteroid dehydrogenase (17 $\beta \mathrm{HSD})$ and 4-hydroxyestrone dioxygenase, respectively, have been confirmed by heterologous expression in Escherichia coli (Chen et al., 2017). Cluster II includes several putative $\beta$-oxidation-related genes, suggesting that CoA ester metabolites are likely to be involved in estrogen degradation. Further metabolite profile analyses enabled the prediction of some possible steps responsible for the aerobic biodegradation of natural estrogens ( $\mathrm{Wu}$ et al., 2018). For instance, the detection of $3 \mathrm{a} \alpha-\mathrm{H}-4 \alpha\left(3^{\prime}\right.$-propanoate $) 7 \mathrm{a}-\beta$-methylhexahydro1,5-indanedione (HIP) in Sphingomonas sp. KC8 growing on E2 pointed out the central role played by this metabolite, in which all the peripheral steroid degradation pathways known so far converge in a common central pathway (Horinouchi et al., 2006; Casabon et al., 2013; Barrientos et al., 2015; Wu et al., 2018).
One of the major drawbacks encountered in studies on the degradative pathways of estrogens in bacteria was the absence of genetic tools to manipulate those pathways by using genetic approaches. Thus, the availability of such genetic tools is a critical factor to further advance in the characterization of these pathways and their utilization for biotechnological purposes.

In this study, we used Novosphingobium tardaugens NBRC 16725 (formerly described as strain ARI-1), which was isolated in a sewage treatment plant in Tokyo (Japan) and is able to use sex hormones such as testosterone (TES), E2, E1, and E3 as sole carbon and energy sources (Fujii et al., 2002, 2003; Ibero et al., 2019a). Recently, we have reported the complete sequence and assembly of this E2-degrading bacterium genome into a single contig (Ibero et al., 2019b). In this study, we have performed transcriptomic analysis that enabled the identification of the catabolic genes involved in estrogen degradation. The development of genetic tools in this strain has allowed, for the first time, to delete some genes of the estrogen degradative pathway and confirm their precise role in estrogen catabolism. Furthermore, we have identified for the first time a CYP450 that performs the 4-hydroxylation of E1 in bacteria and a putative estrogen transport system.

\section{RESULTS}

\section{Whole Transcriptomic Analysis of N. tardaugens Grown on E2}

To determine the expression of genes involved in the degradation of estrogens, we performed RNA-seq analyses in N. tardaugens cultured using PYR (control condition) or E2 as carbon sources. Differential expression analysis yielded 1,368 differentially expressed genes (DEGs) (from 3,980 total genes in genome), where 600 were upregulated and 768 were downregulated in E2 cultures compared to PYR [being fold change (FC) +2 or -2 , respectively, the cutoff value] (Table S1), showing a noticeable contrast in differential expression pattern (Figure S1). The highest level of upregulation $(\mathrm{FC}>10)$ was observed in 61 genes (Table S1), but other 88 genes were notably upregulated $(5<$ FC $<10)$ (Table S1). There are some similarities with the previously described transcriptomic data for this strain when grown on TES compared to PYR (Ibero et al., 2019a): a slight differential induction of genes between EGO55_13695 and EGO55_13795 (SD cluster), induction of the methylmalonyl degradation pathway gene cluster, and high expression levels of genes involved in cobalamin synthesis pathway (Table S1). In our previous work (Ibero et al., 2019a), we demonstrated that a $17 \beta \mathrm{HSD}$, encoded by EGO55_02230, transformed E2 to E1, and we reported similar expression levels in TES to those now observed in E2-grown cells (Table S1), suggesting that its product could be responsible for the 17-dehydrogenation of both TES and E2. However, the differential characteristic of the E2 transcriptome is the upregulation of a region in the genome $(\approx 19 \mathrm{~kb})$ comprising genes EGO55_13520 to EGO55_13600 that will be named estrogen degradation cluster (edc) henceforth. 


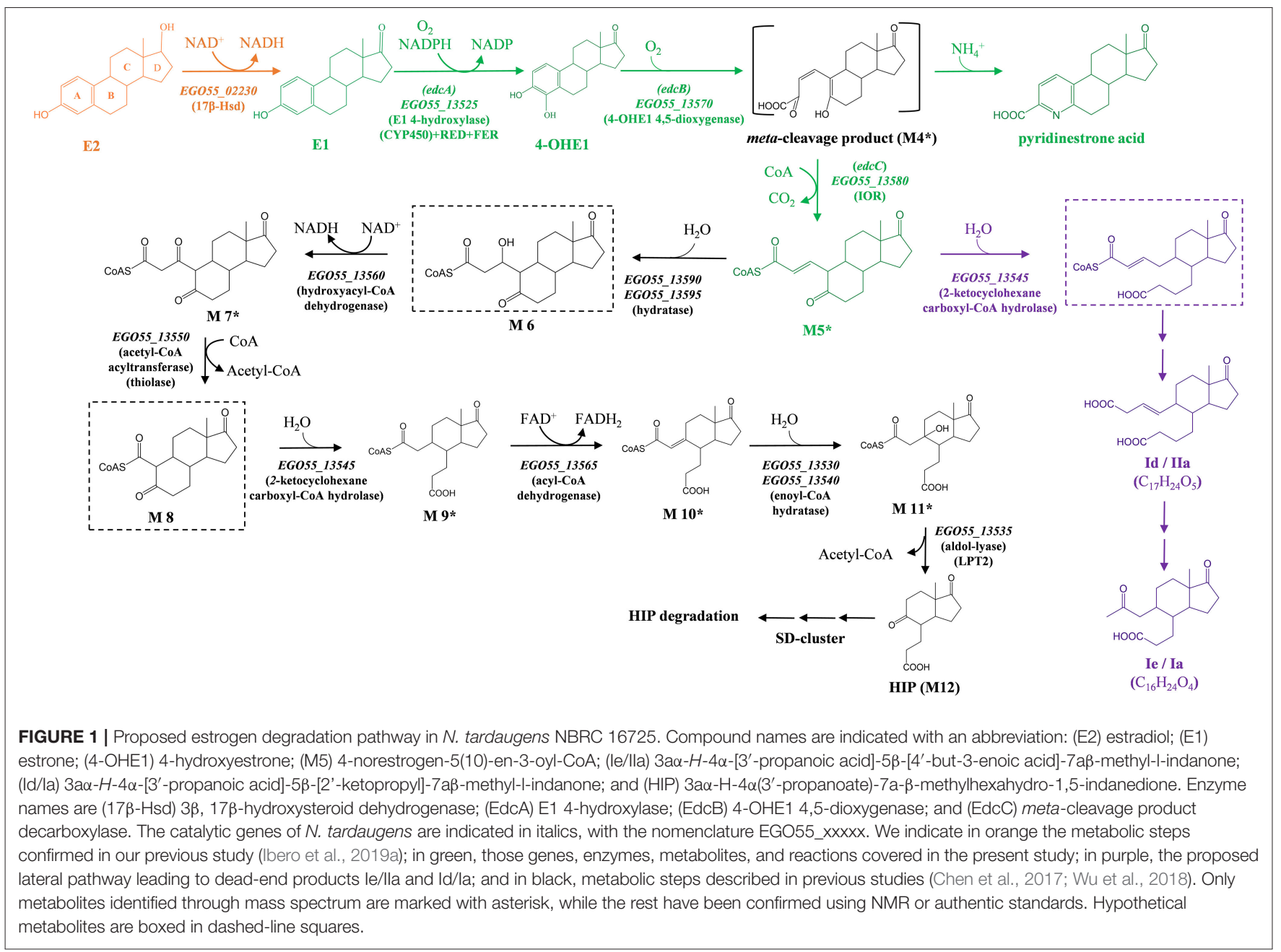

\section{Annotation of the edc Cluster}

The E2 degradation cluster of $N$. tardaugens NBRC 16725 occurs within a 52.8-kb stretch of the chromosome EGO55_13520EGO55_13795 (Figure 2). This region is composed of two large gene clusters: (i) the edc cluster consists of 17 genes which have been shown to be upregulated in E2 in this work (Table S1) and (ii) the $S D$ cluster, which consists of 26 genes that are slightly upregulated in E2 and TES (Table S1) (Ibero et al., 2019a). The 16 genes located within the SD and $e d c$ gene clusters encode a wide variety of proteins, including one regulator, one outer membrane transporter, and several other enzymes related to metabolism (Table S1) that will require a further study to demonstrate their possible involvement in steroid metabolism.

The edc cluster from $N$. tardaugens is similar to cluster II of Sphingomonas sp. KC8 (Chen et al., 2017). Moreover, other clusters similar to the edc cluster can be found in other sequenced bacteria such as Altererythrobacter estronivorus $\mathrm{MH}$ B5 (Qin et al., 2016) and Sphingobium estronivorans AXB (Qin et al., 2020; Figure 2). It is interesting to notice that, in spite of the similarities, the orientations of the genes as well as the gene composition of the operons of the clusters are not identical, which might render some clues about the functionality of the genes.

The edc cluster of $N$. tardaugens consists of two divergent putative operons, OpA (EGO55_13525-EGO55_13565) and OpB (EGO55_13570-EGO55_13600), and another divergently expressed gene EGO55_13520, which encodes a putative TetR transcriptional regulator of the pathway that is currently under study. Operons $\mathrm{OpA}$ and $\mathrm{OpB}$ are divergently transcribed and separated by an intergenic region of $137 \mathrm{bp}$ that putatively encloses both promoter sequences (Figure 2).

The OpA operon encodes a putative cytochrome P450 hydroxylase (CYP450) (EGO55_13525; edcA) whose function in E2 degradation was unknown. There is also a group of genes that encode a hydratase (EGO55_13530; chsH2-like), a lipid-transfer protein (EGO55_13535), an enoyl-CoA hydratase/isomerase (EGO55_13540), a 2ketocyclohexanecarboxyl-CoA hydrolase (BadI-like, thiolase) (EGO55_13545), an acetyl-CoA acyltransferase (thiolase) (EGO55_13550), a 3-hydroxy-3-metylglutaryl-CoA synthase (HMG-CoA synthase) (EGO55_13555), a 3-hydroxyacyl-CoA dehydrogenase (EGO55_13560), and an acyl-CoA dehydrogenase 


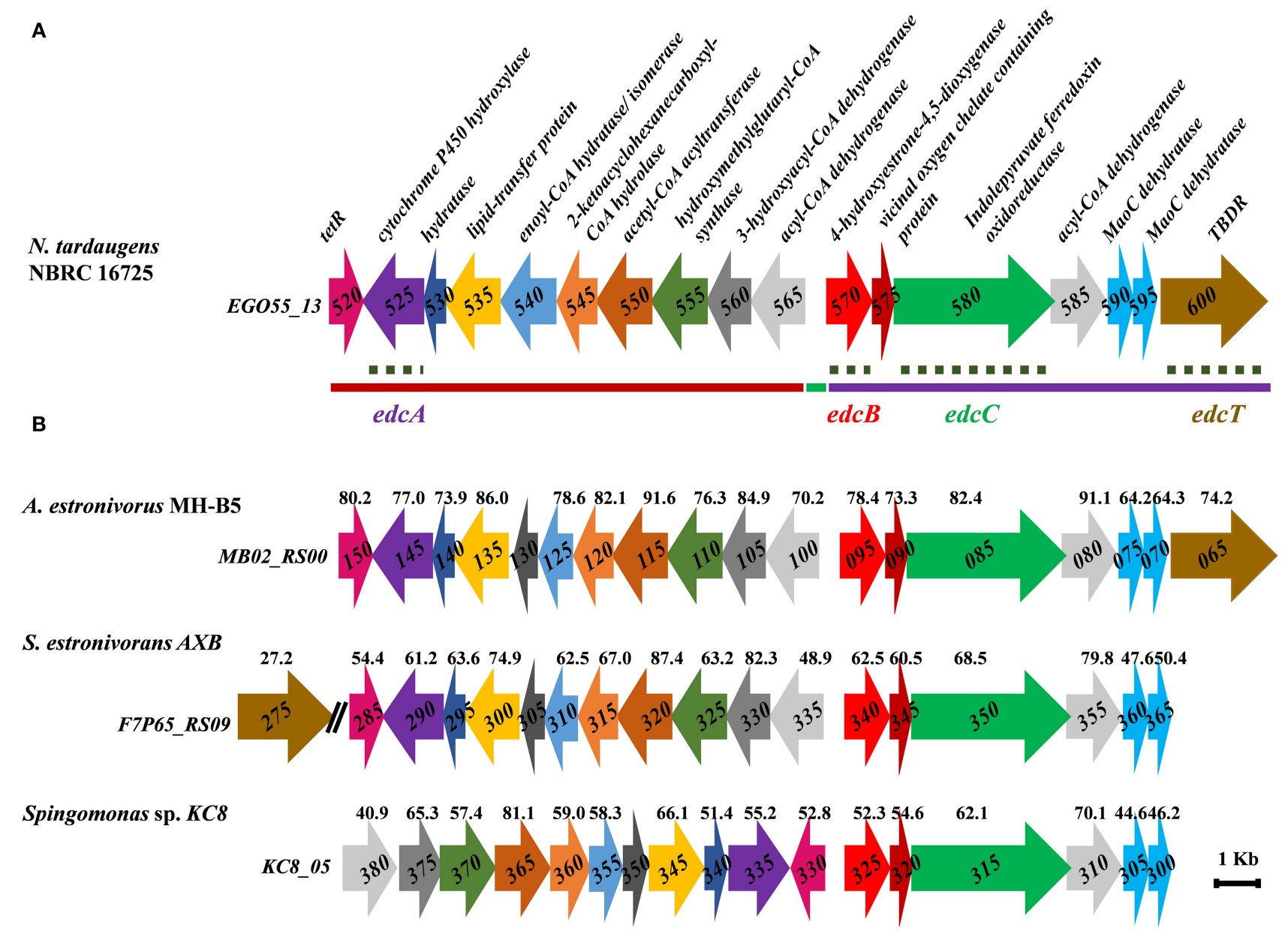

FIGURE 2 | (A) Scheme of the N. tardaugens NBRC 16725 estrogen degradation cluster (edc) (accession number CP034179). Regions deleted by double homologous recombination are depicted with a line: $\triangle$ Prom (green), $\triangle \mathrm{OpA}$ (red), and $\triangle \mathrm{OpB}$ (purple). Gene deletions by double homologous recombination that allowed function confirmation in this study are marked with a dashed line (edcA, edcB, edcC, and edcT). (B) Estrogen degradation gene cluster of $A$. estronivorus MH-B5 (accession number NZ_JRQQ01000001.1), S. estronivorans AXB (accession number NZ_LFCT01000011.1), and Sphingomonas sp. KC8 gene cluster II (accession number CP016306). Genes encoding the same function are pictured in the same color and \% identity of protein products toward those from $N$. tardaugens is shown.

(EGO55_13565). Some of these enzymes are homologous to those involved in lipid metabolism.

It is interesting to notice that the EGO55_13540 gene of $N$. tardaugens is larger than the homologous genes shown in Figure 2. It appears to be a perfect in-frame fusion of the homologous genes KC8_05355 and KC8_05350 from Sphingomonas sp. KC8 (Figure 2). This fusion is not a sequence artifact since it was confirmed by several methods including genome sequencing by Illumina and PacBio as well as by the transcriptome reads of this paper. Thus, the EGO55_13540 gene might have a double function.

The OpB operon encodes a putative 4-hydroxyestrone-4,5dioxygenase (EGO55_13570; edcB) that shares 52.3\% identity with the well-characterized 4-hydroxyestrone-4,5-dioxygenase (OecC) from Sphingomonas sp. KC8 (Chen et al., 2017). This enzyme belongs to the glyoxalase-like family and has been proposed to perform the meta-cleavage reaction of 4-OHE1.
The EGO55_13575 gene encodes a protein that contains a vicinal oxygen chelate (VOC) domain and appears to be a member of a large family of enzymes that catalyze a highly diverse set of reactions, containing enzymes such as glyoxalases I, extradiol dioxygenases, bleomycin resistance proteins, fosfomycin resistance proteins, and methylmalonylCoA epimerases. The EGO55_13580 (edcC) gene encodes a member of the indolepyruvate ferredoxin oxidoreductase (IOR) family. EdcC shares a $62.1 \%$ sequence identity with the protein product of the KC8_05315 gene, belonging to the family of IORs. This enzyme has been proposed for the decarboxylation of the meta-cleavage product in Sphingomonas sp. KC8, based on the activity of other enzymes of this family (Wu et al., 2018). In the metabolism of aromatic amino acids, IORs are responsible for the oxidative decarboxylation of 2-oxo acids, generating the corresponding acetyl-CoA derivative (Mai and Adams, 1994; Kletzin and Adams, 1996; Schut et al., 2001). The C3 and C4 
carbons of the meta-cleavage product have a 2-oxo acid structure, and this compound can be the substrate for an enzyme of this family, such as EdcC. The EGO55_13585 gene encodes an acylCoA dehydrogenase. EGO55_13590 and EGO55_13595 genes encode two MaoC hydratases. The EGO55_13600 gene encodes a putative TonB-dependent receptor (TBDR).

The previously described SD cluster was postulated to be involved in TES degradation in $N$. tardaugens, containing genes responsible for the steroid CD-ring degradation, i.e., HIP degradation (Ibero et al., 2019a), that has been proposed as the convergent metabolite of steroid degradative pathways (Horinouchi et al., 2006; Casabon et al., 2013; Barrientos et al., 2015; Wu et al., 2018).

\section{Functional Analysis of the edc Cluster}

The possibility of transforming $N$. tardaugens has allowed us to use genetic tools to analyze the functionality of the genes involved in estrogen degradation. So far, none of the bacteria able to degrade estrogens has been genetically manipulated, and thus, these tools have open a new scenario to precisely dissect the pathway. To prove the true involvement of the edc gene cluster, comprised of $\mathrm{OpA}$ and $\mathrm{OpB}$ operons, in E2 catabolism, we have constructed two large knockout mutants. Firstly, we have deleted the entire intergenic region, which includes both putative operon promoters $\left(P_{a}-P_{b}\right)$ yielding the $\Delta$ Prom strain: The $\Delta$ Prom mutant will be in principle unable to express all the ecd genes. Secondly, OpA and $\mathrm{OpB}$ operons were deleted, yielding $\triangle \mathrm{OpA}$ and $\triangle \mathrm{OpB}$ mutants, respectively (Figure 2).

As expected, $\triangle$ Prom, $\triangle \mathrm{OpA}$, and $\triangle \mathrm{OpB}$ mutants were unable to grow on estrogens (Figure 3A), but they were able to grow on NB rich medium, and more importantly, in minimal media containing TES as sole carbon and energy sources (Figure 3B). This result confirmed, for the first time with a genetic approach, that the edc cluster is critical for the degradation of estrogens. The OpA and OpB operons have no redundancy, and thus, they cannot be substituted by other operons in the genome. In addition, it also confirmed that none of the edc genes are required for the degradation of androgens like TES in N. tardaugens.

The $\triangle$ Prom, $\triangle \mathrm{OpA}$, and $\triangle \mathrm{OpB}$ mutants were further grown in rich medium supplemented with E2 to study the possible accumulation of steroidal intermediates. Interestingly, the $\Delta$ Prom mutant accumulated E1 (Figure S2), suggesting that $17 \beta \mathrm{HSD}$ activity is encoded outside the edc cluster. In fact, we have not identified a $17 \beta \mathrm{HSD}$ encoding gene in the edc cluster, suggesting that this activity was encoded in other chromosomal locus. This result is in agreement with the observation that a $17 \beta \mathrm{HSD}$ encoding gene is found out of cluster II of Sphingomonas sp. KC8 (Chen et al., 2017). This result also demonstrates that, without the enzymes encoded in the edc cluster, the metabolism of E1 cannot progress any further, suggesting that the second proposed step in the estrogen degradation pathway, i.e., the hydroxylation of $\mathrm{E} 1$, is more probably encoded within the cluster. The accumulation of $\mathrm{E} 1$ was also detected in the $\Delta \mathrm{OpA}$ (Figure S2), suggesting that the enzyme responsible for the hydroxylation of E1 should be encoded in the OpA operon. The organic fraction extracted from cultures of $\triangle$ Prom and $\triangle O p A$ mutants did not show any other intermediate different from E1,

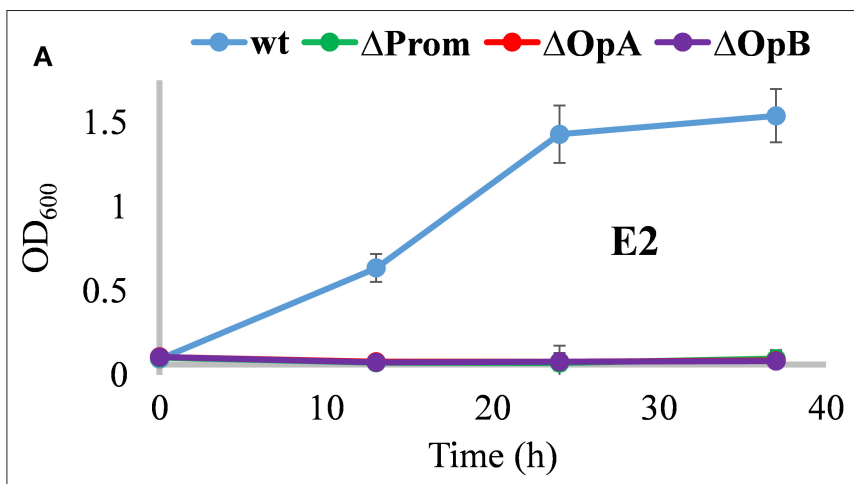

B

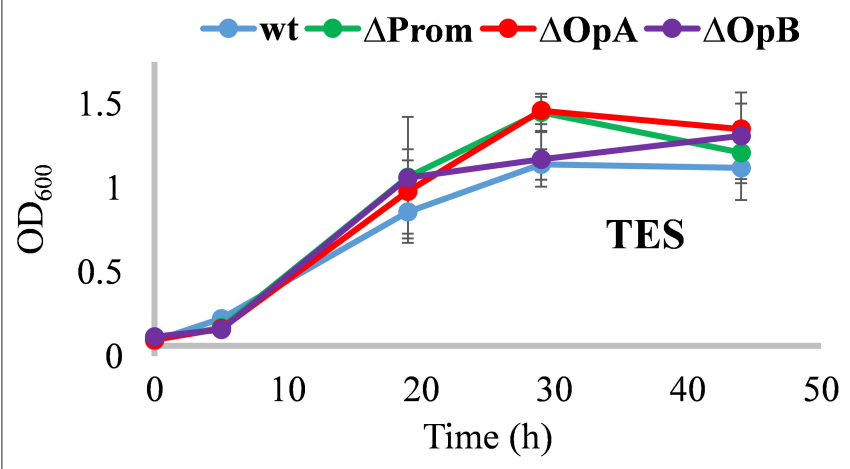

FIGURE 3 | Growth phenotype of N. tardaugens NBRC 16725 (blue), $\Delta$ Prom (green), $\triangle \mathrm{OpA}$ (red), and $\triangle \mathrm{OpB}$ (purple) strains. Growth curves (OD $600 \mathrm{~nm}$ ) in minimal medium M63 supplemented with (A) 2 mM E2 and (B) $1.89 \mathrm{mM}$ TES (data corresponding to biological triplicates and error bars show standard deviation).

suggesting that E1 cannot be modified by other enzymes of $N$. tardaugens apart from those encoded by the edc cluster.

Interestingly, HPLC-MS analysis of cultures of $\triangle \mathrm{OpB}$ mutant identified a compound with an $\mathrm{m} / z$ of 286 , sharing elution time and $\mathrm{m} / \mathrm{z}$ with 4 -OHE1 commercial standard (Figure 4). The OpB operon contains the EGO55_13570 gene, annotated as a putative 2,3-dihydroxybiphenyl 1,2-dioxygenase, which shows a $52.3 \%$ identity to oecC (4-hydroxyestrone-4,5-dioxygenase), which transforms 4-OHE1 into the meta-cleavage product (Chen et al., 2017). Therefore, the accumulation of 4-OHE1 might be explained by the absence of this dioxygenase activity. Besides, the detection of 4-OHE1 in $\triangle \mathrm{OpB}$ mutant cultures suggests that the hydroxylase activity of E1 is encoded in the OpA operon.

\section{Analysis of $\mathbf{N}$. tardaugens Mutants Carrying Specific Deletions of Some edc Genes}

To determine the function of some edc genes in E2 metabolism, three genes were deleted. Using this genetic approach, we have checked the ability of the mutants to grow on E2, compared to the wild-type strain, and investigated the accumulation of intermediates that might render information about the 


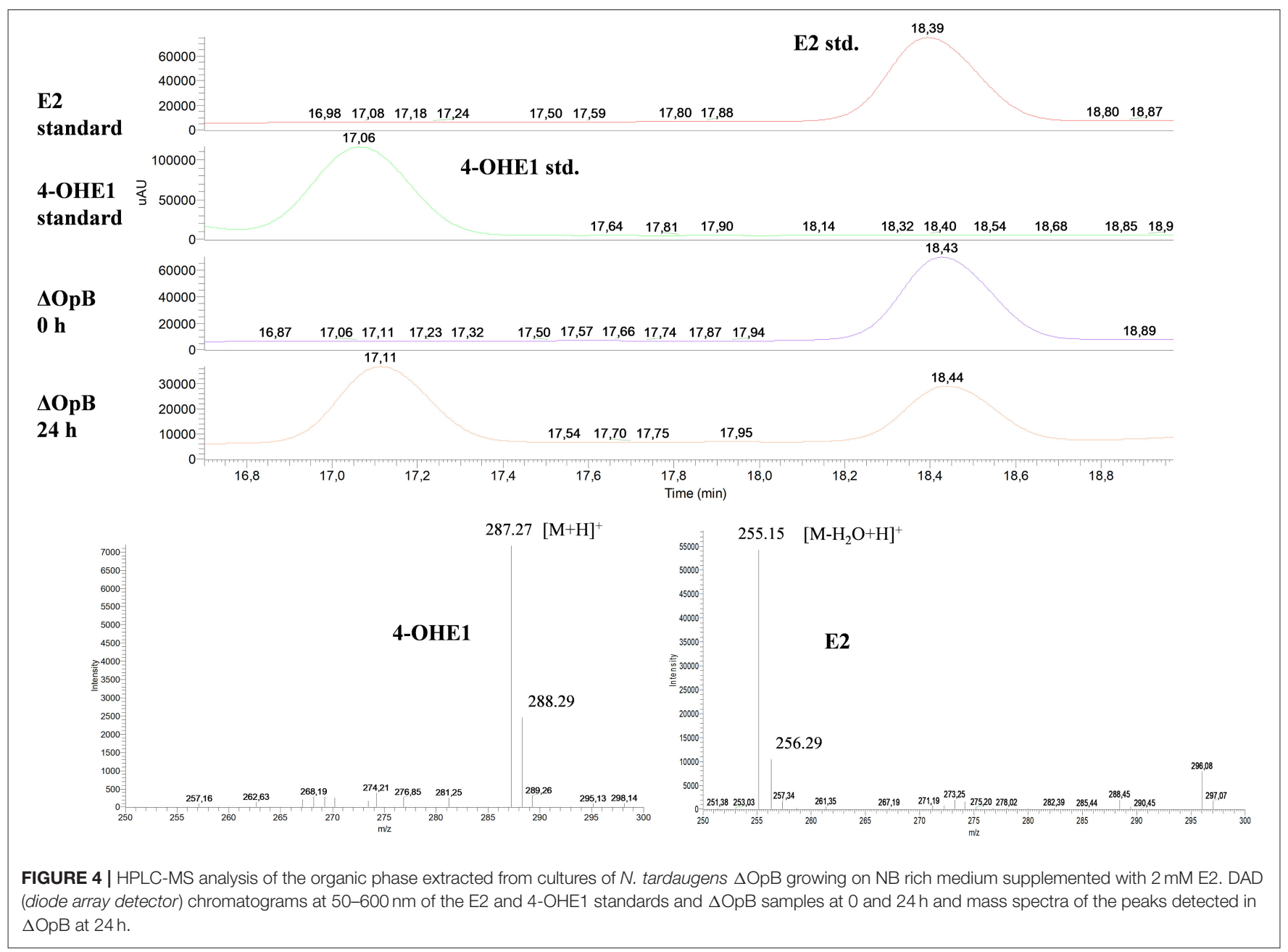

functionality of these genes. In this sense, $\Delta$ edcA, $\Delta$ edcB, and $\triangle \mathrm{edcC}$ mutant strains were constructed, in which cytochrome P450 (EGO55_13525; edcA), putative extradiol dioxygenase (EGO55_13570; edcB), and putative indolepyruvate ferredoxin oxidoreductase (EGO55_13580; edcC), which might be responsible for the three first steps of the E1 degradation pathway, were deleted, respectively (Figure 2).

$\triangle$ edcA, $\Delta$ edcB, and $\triangle$ edcC mutants showed an impaired growth on E2 as sole carbon and energy source (Figure 5A). Significantly, the ability of the mutants to grow on E2 was restored by the trans complementation of the mutants expressing the deleted genes on a plasmid (Figure 5B), demonstrating that the deletions have only affected the specific genes.

When these mutants were cultured in NB rich medium supplemented with E2 to detect the accumulation of intermediates in the culture, the HPLC-MS analysis showed a characteristic metabolite accumulation pattern for each mutant.

Firstly, the $\triangle \mathrm{edcA}$ mutant accumulated E1 (Figure 6), suggesting that the EGO55_13525 gene could be involved in E1 hydroxylation. To confirm this hypothesis, the $\Delta$ Prom mutant strain, lacking the ability to express all the genes from the edc cluster, was complemented with a plasmid expressing the edcA gene. Interestingly, when the $\triangle$ Prom (pSEVA23ecdA) strain grew in NB rich medium supplemented with E2, we detected the production of 4-OHE1 (Figure 7). This result supports the hypothesis that cytochrome P450 (CYP450) EdcA is responsible for the hydroxylation of E1. This assumption was not unexpected if we consider that E1 and E2 hydroxylation is carried out in mammals by a CYP450 (Lønning et al., 2011). However, our result does not agree with the proposal of Chen et al. (2017) who have suggested that the oecB gene, encoding a putative monooxygenase, is responsible for E1 hydroxylation in Sphingomonas KC8.

Secondly, the $\triangle$ edcB mutant strain accumulated 4-OHE1 (Figure 8), supporting the hypothesis that the EGO55_13570 gene encodes a 4-hydroxyestrone-4,5-dioxygenase, in this case in agreement with the proposal of Chen et al. (2017).

Finally, the $\triangle$ edcC mutant accumulated a metabolite of $\mathrm{m} / \mathrm{z}$ 300 that could correspond to pyridinestrone acid (Figure 9). This compound was described as a side product in Sphingomonas sp. KC8 that spontaneously derives from the meta-cleavage product in the presence of ammonia (Chen et al., 2017). This result suggests that the meta-cleavage product of ring A should be the substrate of EdcC. In agreement with this result, the homologous 

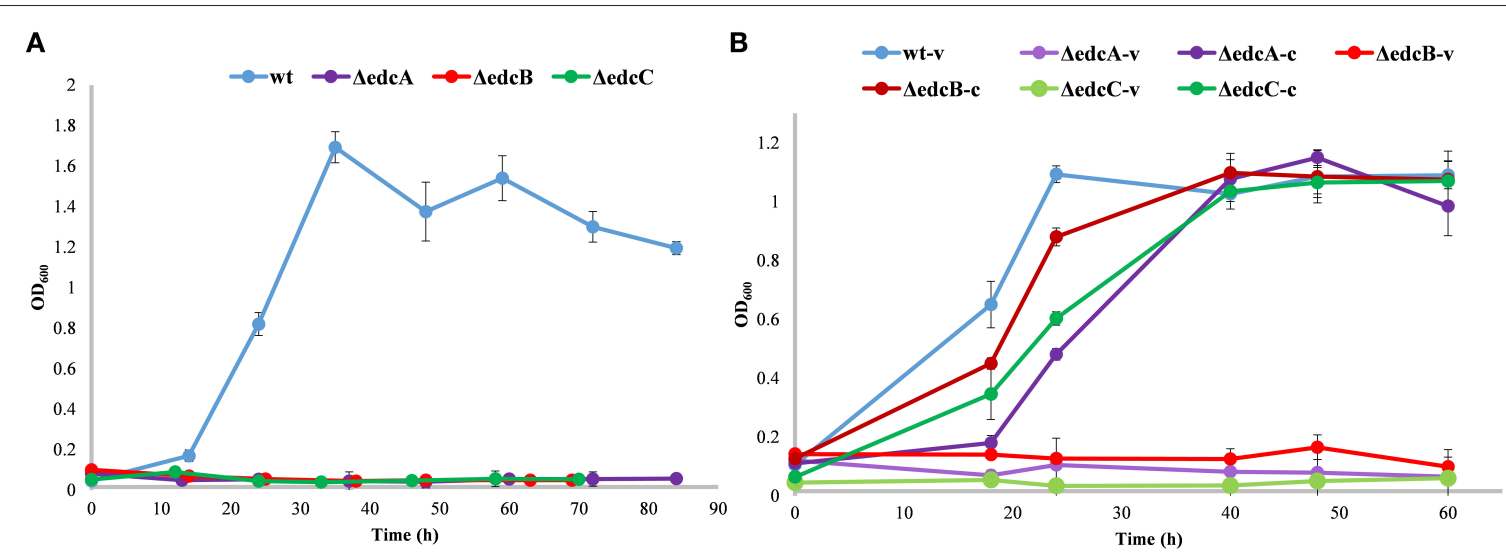

FIGURE 5 | Growth curves $\left(\mathrm{OD}_{600}\right.$ ) in minimal medium M63 supplemented with 2 mM E2. (A) Growth of N. tardaugens NBRC 16725 (blue), $\Delta$ edcA (purple), $\Delta$ edcB (red), and $\triangle$ edcC (green). (B) Growth of $N$. tardaugens NBRC 16725 and the mutant strains with pSEVA23PlexA, (-v), and complemented with the corresponding deleted gene, $(-c)$. Data corresponding to biological triplicates and error bars show standard deviation.

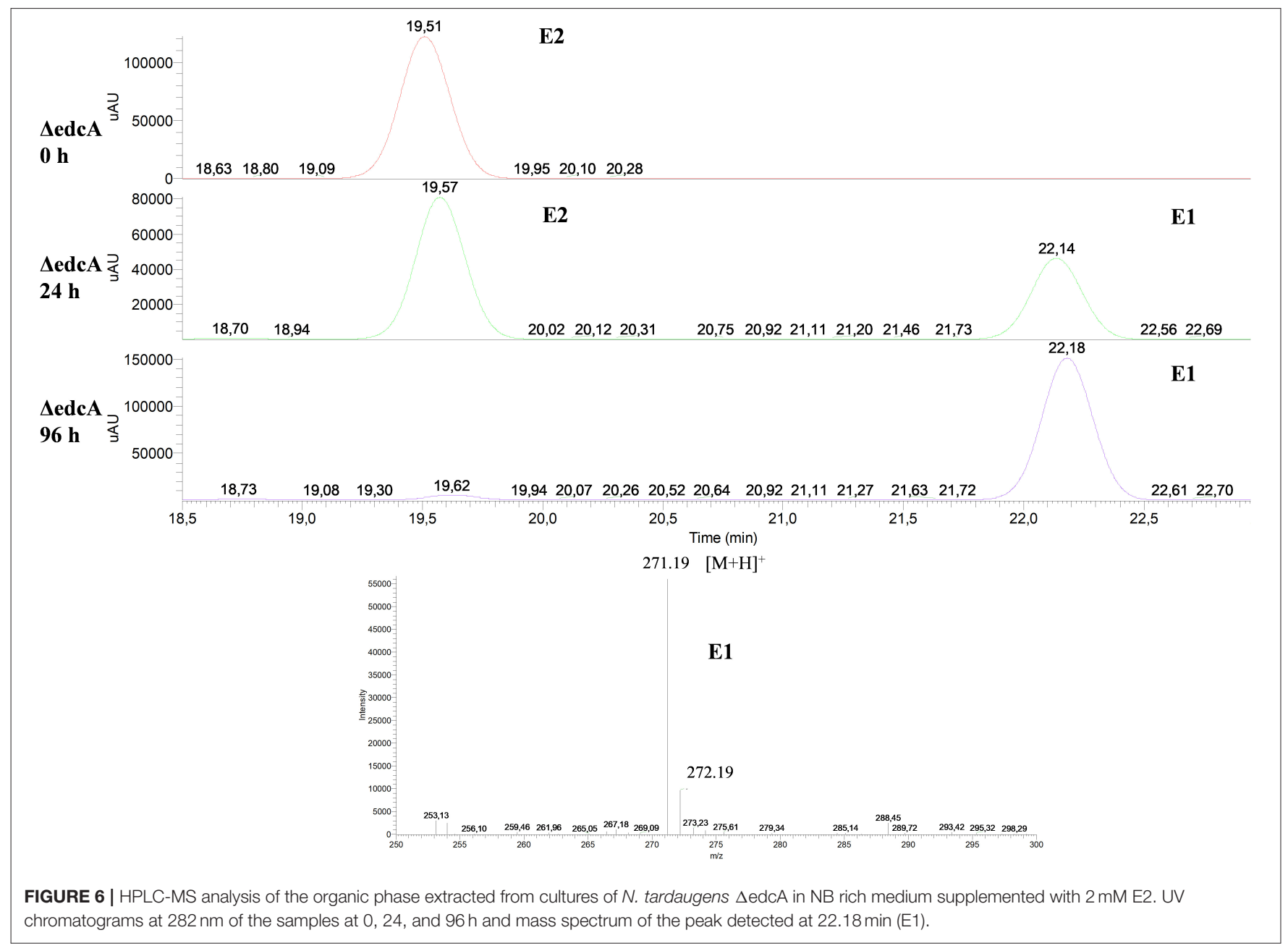

indolepyruvate ferredoxin oxidoreductase present in cluster II of KC8 has been proposed as an enzyme that decarboxylates the meta-cleavage product of ring A and, at the same time, ligates a $\mathrm{CoA}$ molecule to the resulting new carboxylic residue to facilitate further degradation (Wu et al., 2018). In the absence of this enzyme, the resulting meta-cleavage product of ring A 

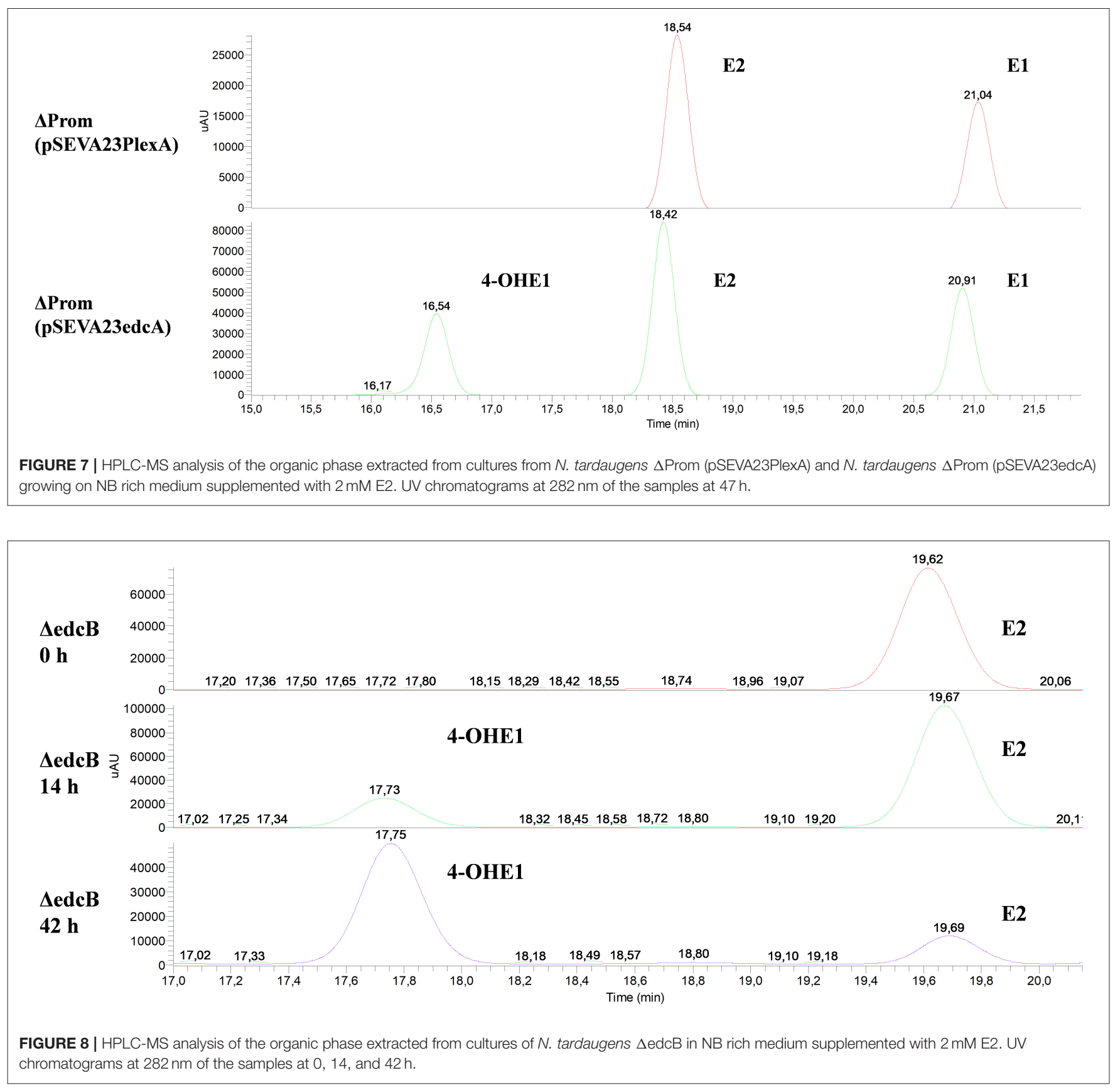

cannot progress, and therefore, it is spontaneously cyclized with ammonium to render a pyridine molecule.

\section{EdcA Catalyzes E1 Hydroxylation in vitro}

To determine the activity of CYP450 EdcA in vitro, the edcA gene was cloned into $E$. coli $\mathrm{pET} 29 \mathrm{a}$ expression vector generating pETedcA plasmid that allows the overexpression of EdcA in E. coli BL21 (DE3) as a C-terminal His-tagged fusion protein. The overproduction of the tagged protein in the presence of isopropyl- $\beta$-D-thiogalactopyranoside (IPTG) was observed by
SDS-PAGE in the protein extracts (Figure S3). The enzymatic activity of CYP450 was examined in vitro, and the oxidation of E1 after 30 min of incubation using E. coli BL21 (DE3) (pETedcA) crude extracts was observed, as judged from the appearance of a new peak in the HPLC chromatograms (Figure 10). The relative retention times $(\mathrm{Rt})$ and mass spectrum of the product were consistent with those of 4-OHE1 (Rt $16.10 \mathrm{~min}, \mathrm{~m} / z$ 287). When the hydroxylase activity of EdcA was tested on other putative steroidal substrates like E2 and E3, the enzyme was able to hydroxylate E2, but not E3 (Figure S4). 


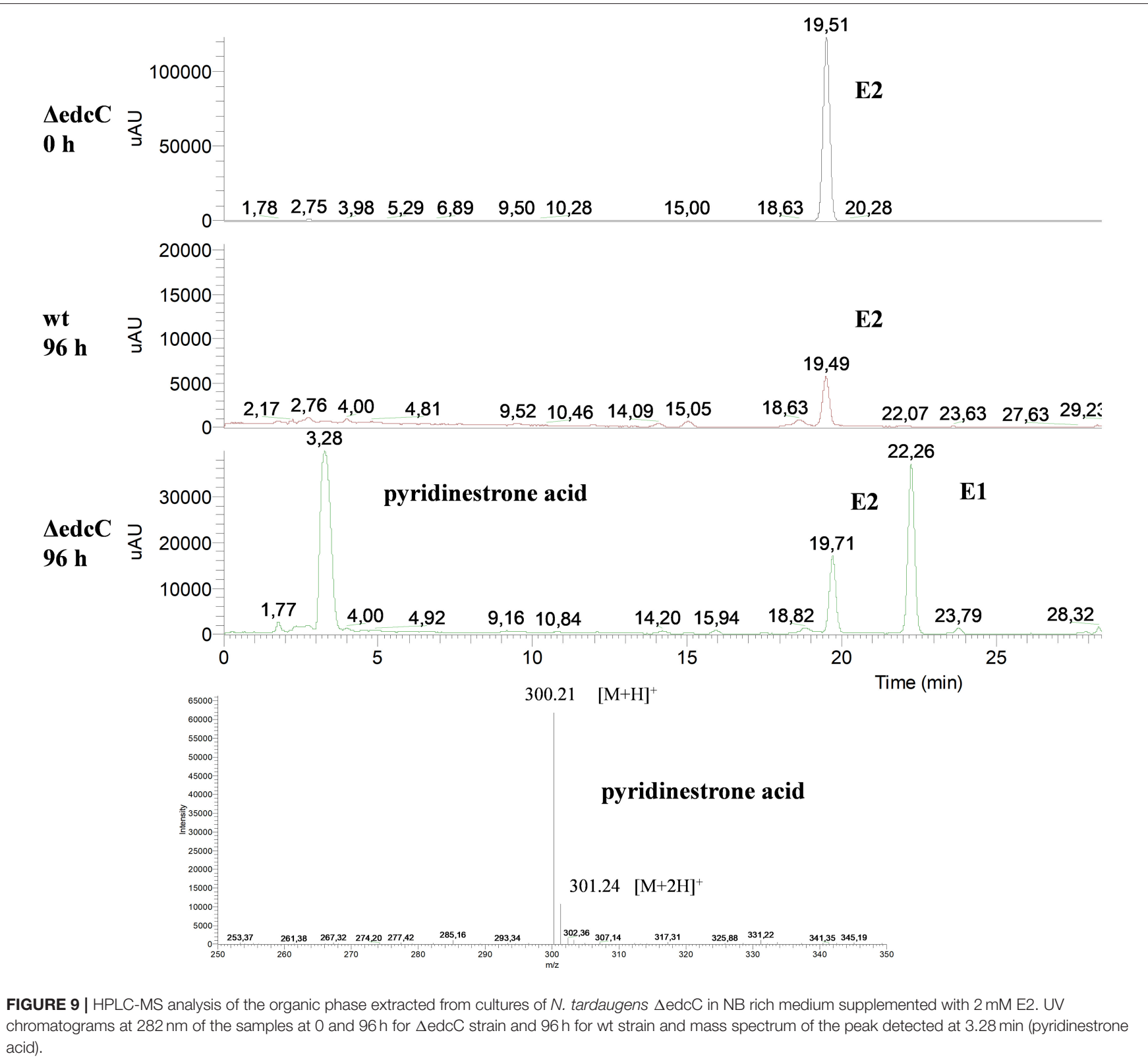

\section{Analyzing the Role of the edcB Gene by Additional Genetic Studies}

To prove that the $e d c B$ gene encodes a 4-hydroxyestrone-4,5dioxygenase, we have performed additional genetic studies. In this sense, EGO55_13570 (edcB) and EGO55_13525 (edcA) genes were cloned together in a PSEVA23PlexA vector under the control of the $P_{b}$ promoter, which includes the intergenic region of the edc cluster, generating the pSEVA237-Pb-edcAB plasmid (Figure S5) that was transformed into $\triangle$ Prom mutant, yielding the $\Delta$ Prom (pSEVA237-Pb-edcAB) strain. To be used as controls, we have also constructed the strain $\triangle$ Prom (pSEVA237- $\mathrm{Pb}$ edcA), carrying only the $e c d A$ gene under the control of the $P_{b}$ promoter and the strain $\triangle$ Prom (pSEVA237PlexA) carrying the empty plasmid without any gene. It should be noticed that the strain $\triangle$ Prom (pSEVA237- $\mathrm{Pb}$-edcA) is very similar to the strain $\triangle$ Prom (pSEVA23ecdA) mentioned above, but in the last case, the $e d c A$ gene is under control of the $P_{\text {lexA }}$ promoter.

$\triangle$ Prom (pSEVA237-Pb-edcAB), $\triangle$ Prom (pSEVA237- $\mathrm{Pb}$ edcA), and $\triangle$ Prom (pSEVA237PlexA) strains were grown on NB rich medium supplemented with $\mathrm{E} 1$, and the organic phase was extracted to analyze the accumulation of metabolites in the cultures. The HPLC-MS analysis of $\triangle$ Prom (pSEVA237$\mathrm{Pb}$-edcAB) cultures showed a peak at $3.13 \mathrm{~min}$, which did not appear in the $\triangle$ Prom (pSEVA23PlexA) and $\triangle$ Prom (pSEVA237$\mathrm{Pb}$-edcA) strains used as controls (Figure 11). As expected, the $\triangle$ Prom (pSEVA237-Pb-edcA) accumulates 4-OHE1, confirming the results shown by the $\triangle$ Prom (pSEVA23edcA) strain (Figure 7). The peak at $3.13 \mathrm{~min}$ accumulated in the $\Delta$ Prom 


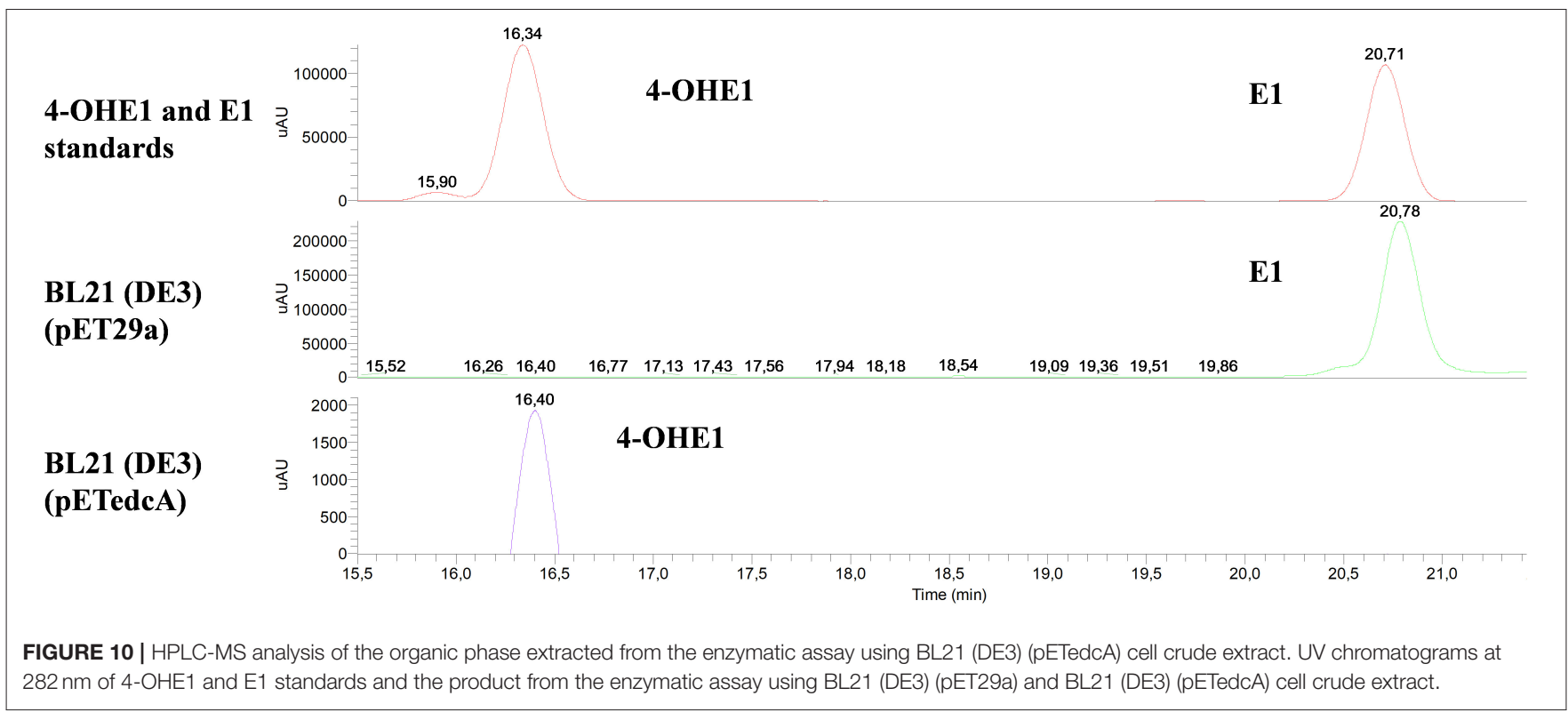

(pSEVA237-Pb-edcAB) strain corresponds to a compound of $\mathrm{m} / \mathrm{z}$ 300, consistent with pyridinestrone acid (Chen et al., 2017). This result strongly supports that EdcB is using 4-OHE1 as substrate and it is required for opening ring $\mathrm{A}$.

\section{Analyzing the Role of the edcC Gene by Additional Genetic Studies}

To demonstrate that the edcC gene is required in the next step of estrogen degradation, after cleavage of 4-OHE1, we have cloned the $e d c C$ gene into plasmid pSEVA237-Pb-edcAB delivering the pSEVA237-Pb-edcABC plasmid (Figure S5), which was transformed into the $\triangle$ Prom strain. The resulting strain, $\triangle$ Prom (pSEVA237-Pb-edcABC), was grown on $\mathrm{NB}$ rich medium supplemented with E1, and the extracted organic fraction was analyzed by HPLC-MS. The rationale of this experiment is based on the fact that the accumulation of pyridinestrone acid resulting from the consecutive activities of EdcA and EdcB should be reduced or even avoided in the presence of the following decarboxylating activity of EdcC. Figure 12 shows the accumulation of a compound with an elution time of $12.76 \mathrm{~min}$ that is only detected in the organic fraction from the culture of the $\triangle$ Prom (pSEVA237-Pb-edcABC) strain (Figure 12). This peak might correspond to an ion $\left(\mathrm{M}-\mathrm{H}_{2} \mathrm{O}+\mathrm{H}\right)^{+}$of a compound of mass 290 without one water molecule. This mass is in agreement with the mass of the deconjugated (i.e., without CoA) M5 compound (Figure 1), proposed as an intermediate derived from the decarboxylation and activation with CoA of the metacleavage product in Shingomonas sp. KC8 (Wu et al., 2018). The accumulation of this compound in the culture of the $\Delta$ Prom (pSEVA237-Pb-edcABC) strain supports the role of EdcC in the decarboxylation of the meta-cleavage product derived from the dioxygenase activity of EdcB in $N$. tardaugens.

\section{Analyzing the Role of edcA in E3 Degradation}

$N$. tardaugens is able to metabolize E3 using it as a sole carbon and energy source to grow, but the mechanisms involved in this catabolism remain unknown (Fujii et al., 2002). To investigate E3 catabolism, the wild-type and $\Delta$ edcA mutant strains of $N$. tardaugens were cultivated in E3 as a sole carbon and energy source. The growth curve showed that the $\triangle$ edcA mutant was unable to grow on E3 (Figure 13A), suggesting that $e d c A$ is essential in the degradation of E3 in $N$. tardaugens. However, this experiment did not allow us to know if EdcA could hydroxylate E3 or if E3 has to be previously transformed into other intermediate to be hydroxylated and degraded afterwards. In fact, we have not observed in vitro the hydroxylation of E3 by CYP 450 (see above).

To investigate these options in vivo, $\triangle$ Prom (pSEVA23PlexA) and $\triangle$ Prom (pSEVA23ecdA) strains were grown on NB rich medium supplemented with E3, and the organic fraction extracted from the culture medium was analyzed by HPLC-MS.

The accumulation of a compound eluting at $9.65 \mathrm{~min}$ of $\mathrm{m} / \mathrm{z}$ $287(\mathrm{M}+\mathrm{H})^{+}$was observed in the organic fraction from the culture of the $\triangle$ Prom (pSEVA23PlexA) strain. However, this compound was not observed in the $\triangle$ Prom (pSEVA23-ecdA) strain, expressing edcA (Figure 13B). The detected ion could correspond to a compound with a keto group of mass 286, resulting from the dehydrogenation of one hydroxyl group of E3 at position 16 (16-keto-E2) or $17(16 \alpha-\mathrm{OH}-\mathrm{E} 1)$ (Figure 13D). We believe that most probably this compound should correspond to $16 \alpha-\mathrm{OH}-\mathrm{E} 1$ by the action of a $17 \beta \mathrm{HSD}$. This reaction should be similar to the reaction that transforms E2 into E1. Nevertheless, we cannot ascertain that the process is performed by the same enzyme, since there are several putative $17 \beta \mathrm{HSD}$ encoded in the genome of $N$. tardaugens. 


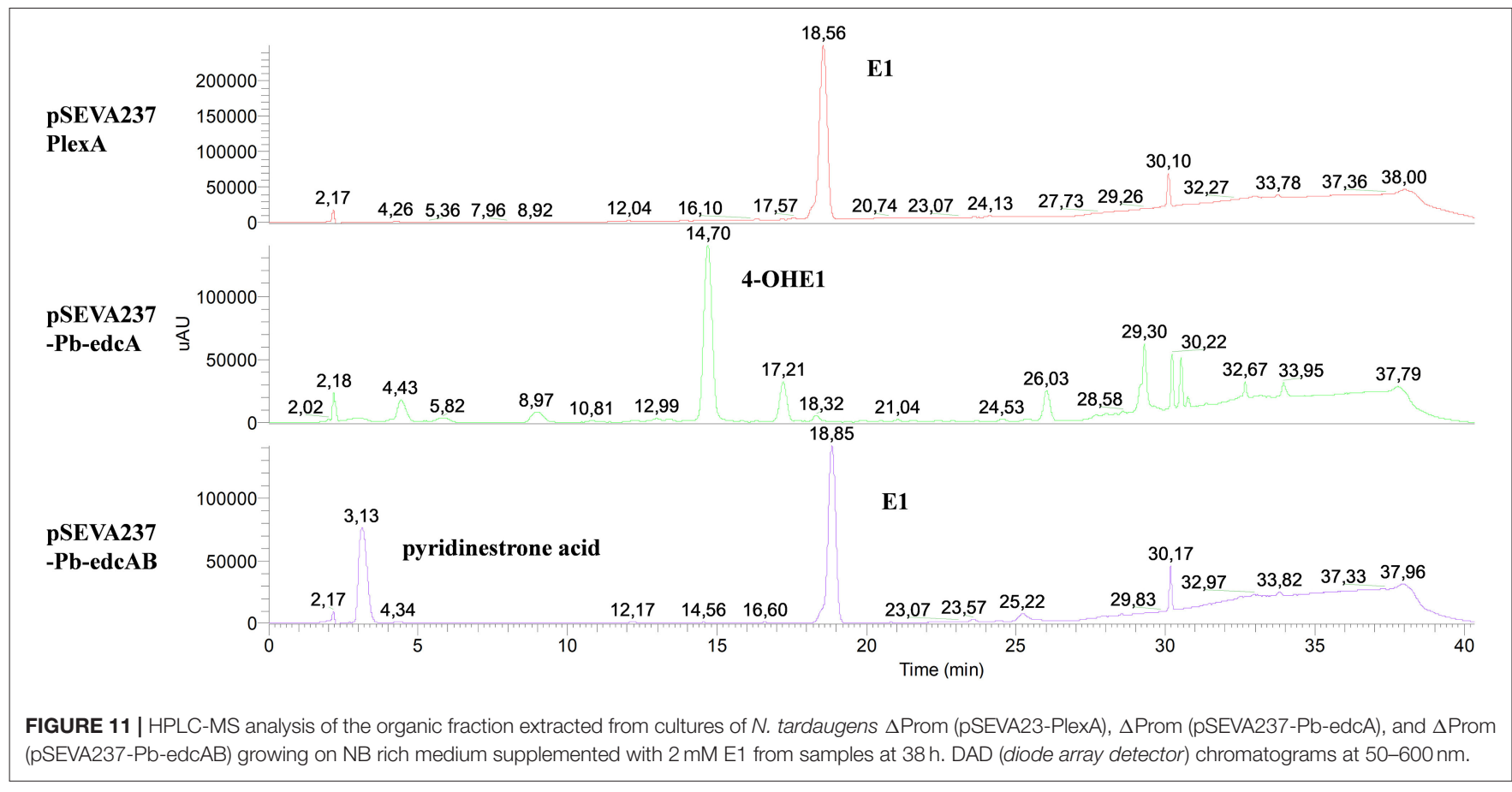

On the other hand, the $\triangle$ Prom (pSEVA23ecdA) strain accumulated a compound with $\mathrm{m} / z$ of $303(\mathrm{M}+\mathrm{H})^{+}$at $5.79 \mathrm{~min}$ (Figure 13C). This compound has a difference in mass of 16 that could correspond most probably to the addition of a hydroxyl group at $\mathrm{C} 4$ in $16 \alpha-\mathrm{OH}-\mathrm{E} 1$. Unfortunately, since we do not have a standard of this compound, we could not test the hydroxylation of $16 \alpha-\mathrm{OH}-\mathrm{E} 1$ by CYP450 in vitro.

All these results suggest that E3 and E2 are poor or null substrates for CYP450 in vitro; however, it can hydroxylate E1 (in vivo and in vitro) and 16 $\alpha$-OHE1 (in vivo) reinforcing the idea that the keto group at C17 is required by CYP450 EcdA to carry out the $\mathrm{C} 4$ hydroxylation of estrogens. Moreover, these results suggest that the edc cluster is involved in the degradation of E3.

\section{Analysis of E2 Transport}

The edcT (EGO55_13600) gene, located at the end of the OpB operon (Figure 2), encodes a putative TonB-dependent receptor, whose expression is upregulated 91-fold in the presence of E2. TBDRs are bacterial outer membrane proteins that bind and transport ferric chelates, called siderophores, as well as vitamin $\mathrm{B}_{12}$, nickel complexes, and carbohydrates (Noinaj et al., 2010). To study the function of the putative TonB-dependent receptor EdcT on E2 catabolism, the EGO55_13600 gene was deleted (Figure 2). The resulting $\Delta$ edcT mutant showed a decrease in growth rate and an increased lag phase with respect to the wild-type strain (Figure 14), suggesting that the TonBdependent receptor protein could be involved in the transport of E2 into the cell. This result is also supported by the partial reversion of this behavior achieved by the $\triangle$ edcT (pSEVA23edcT) strain expressing the edcT gene cloned in plasmid pSEVA23 (Figure 14). This is, to the best of our knowledge, the first experimental result that links the transport of steroids to a TonB-dependent receptor.

\section{DISCUSSION}

In this work, we have used different experimental approaches to investigate the aerobic catabolism of estrogens in $N$. tardaugens. The global transcriptomic analysis in E2-grown cells has allowed us to identify the edc cluster, responsible for the aerobic degradation of $\mathrm{A}$ and $\mathrm{B}$ rings of E2 in this bacterium. The expression of the edc genes showed a remarkable induction upon growth on E2 (FC ranging from 16.6 to 91.7) that corresponded to the highest level of expression observed in the whole transcriptome. Besides the edc cluster, the induction of the methylmalonyl degradation pathway gene cluster supports the formation of propionyl-CoA in the lower HIP degradation pathway, due to the lack of methylcitrate cycle genes in the $N$. tardaugens genome. Moreover, the upregulation of genes involved in the cobalamin synthesis pathway is consistent with the requirement of this cofactor by the methylmalonyl-CoA mutase, which is upregulated in the presence of E2.

The data presented in this work have been analyzed in the light of the results obtained in Sphingomonas strain KC8 (Chen et al., 2017; Wu et al., 2018). Here, we propose an E2 catabolic pathway in $N$. tardaugens (Figure 1) including the degradation of E2 to HIP, since this compound is a common intermediate in steroid catabolism in all bacteria studied so far (Horinouchi et al., 2006; Casabon et al., 2013; Barrientos et al., 2015; Wu et al., 2018). The gene annotation of the edc cluster has allowed us to ascribe the genes to the proposed steps of the pathway with the exception of EGO55_13555 and EGO55_13575 (Figure 1). EGO55_13555 encoded a protein homologous to 


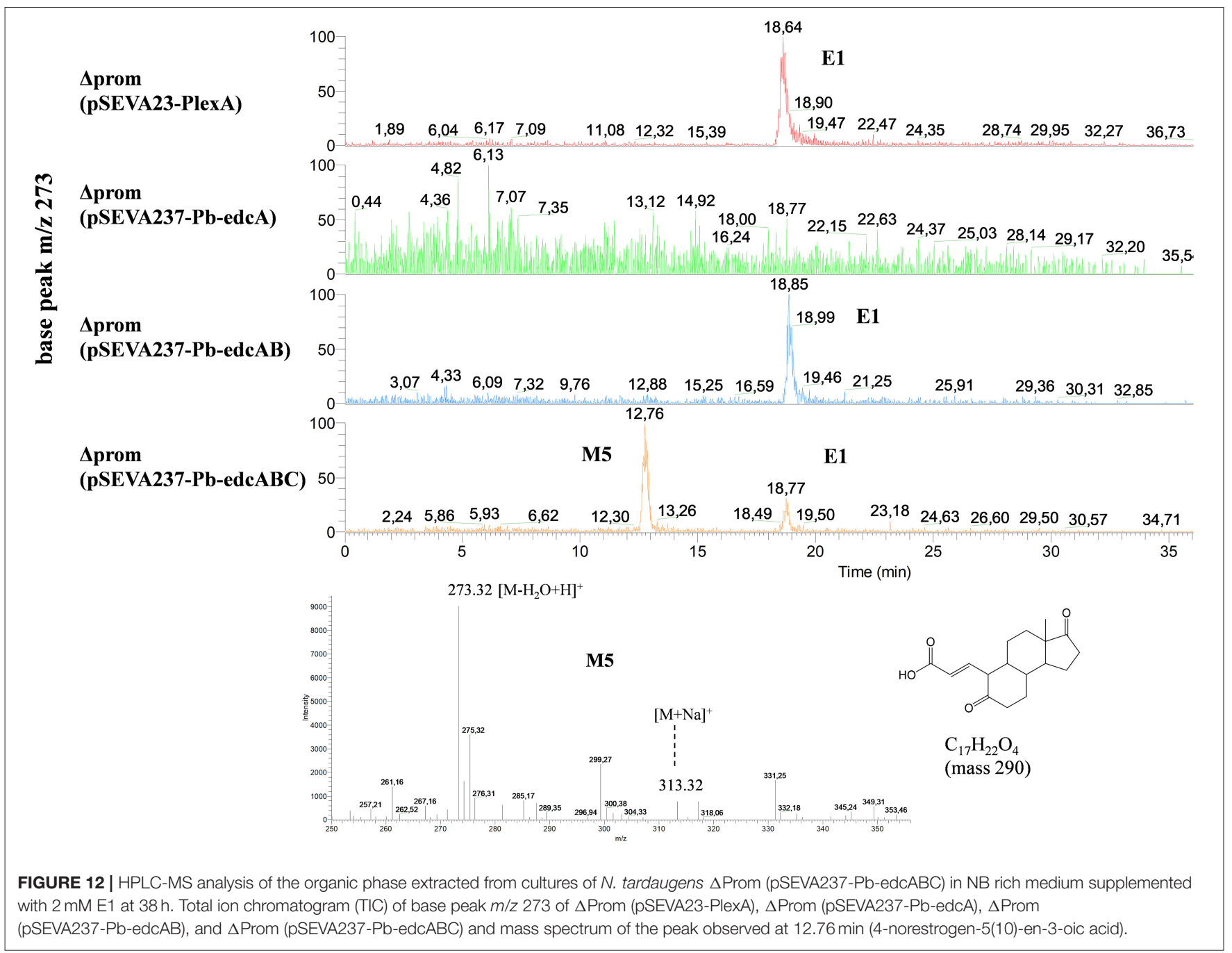

HMG-CoA synthases. These enzymes catalyze the condensation of acetyl-CoA with acetoacetyl-CoA. An anabolic reaction like this one does not appear to make sense in the estrogen degradative pathway. A phylogenetic analysis of this gene revealed that, although it can be classified as HMG-CoA synthase, it belongs to a different group in the current tree of HMG-CoA synthases (Figure S6). This finding suggests that this enzyme does not have a condensation activity and might have other activities (e.g., thiolase). In this sense, these enzymes belong to a thiolase superfamily including biosynthetic (HMG-CoA synthases, chalcone synthases, polyketide synthases and related enzymes) or degradative thiolases (Heath and Rock, 2002). EGO55_13575 encodes a protein member of a large family of enzymes containing a VOC domain that catalyze a highly diverse set of chemistries, some of them oxidative reactions ( $\mathrm{He}$ and Moran, 2011). Enzymes in this VOC superfamily are represented by four families: isomerase, nucleophilic addition, extradiol dioxygenase, and $\alpha$-keto acid oxygenase (He and Moran, 2011). Among those, the protein encoded by EGO55_13575 does not seem to be involved in nucleophilic addition (fosfomicyn resistance) nor isomerase (glyoxylase or methylmalonyl-CoA epimerase) reactions. Although the methylmalonyl pathway is proposed to be involved in propionyl-CoA (derived from HIP degradation) metabolism, the position of EGO55_13575 between genes involved in ring A opening and decarboxylation suggests that it might act in earlier steps of the pathway. Whereas, other functions performed by VOC proteins, i.e., extradiol dioxygenase or $\alpha$-keto acid oxygenase, seem to fit better the oxidation processes expected in this upper pathway, the diol structure on aromatic ring $\mathrm{A}$ is cleaved by $\mathrm{EdcB}$, so the latter seems to be the only reasonable option. In this sense, the enzyme could be involved in reducing the length in carbons of the alkyl chain generated after ring cleavage, allowing the conversion of Id to Ie, for instance (Figure 1).

The aerobic catabolism of E2 starts with the dehydrogenation of the hydroxyl group at position $17 \beta$ to produce E1. The $N$. tardaugens genome includes 16 homologous proteins encoding putative $17 \beta$-HSDs, and none of them are encoded within the edc cluster (Ibero et al., 2019a). Probably, such diversity of enzymes makes it evolutionary unnecessary to include this 

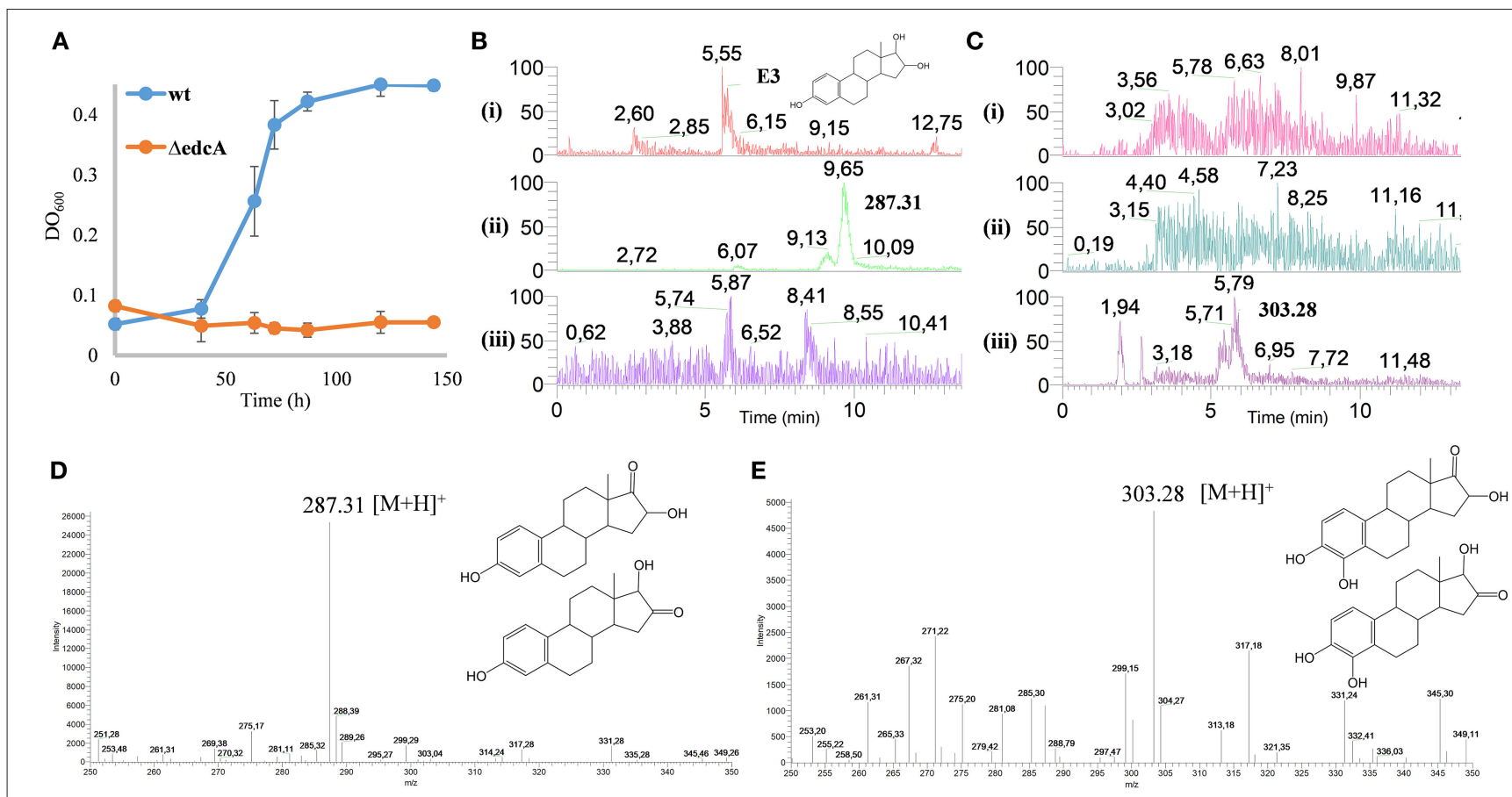

FIGURE 13 | (A) Growth curves (OD 600 ) on M63 minimal medium with 1.89 mM E3 of N. tardaugens NBRC 16725 and $\triangle$ edcA. Data corresponding to biological triplicates and error bars show standard deviation. HPLC-MS analysis of the organic fraction extracted from cultures of N. tardaugens $\triangle$ Prom (pSEVA23-PlexA) and N. tardaugens $\Delta$ Prom (pSEVA23-edcA) in NB rich medium supplemented with $1.89 \mathrm{mM} \mathrm{E3}$, at $38 \mathrm{~h}$. Total ion chromatogram (TIC) of base peak $\mathrm{m} / \mathrm{z}$ (B) 287 and (C) 303. The samples correspond to the control of non-inoculated medium, (i); N. tardaugens $\triangle$ Prom (pSEVA23-PlexA) strain, (ii); and N. tardaugens $\triangle$ Prom (pSEVA23-edcA) strain, (iii). Mass spectrum of the peak observed at (D) $9.65 \mathrm{~min}$ and (E) at $5.79 \mathrm{~min}$.

enzyme in the steroid degradative clusters that require a $\mathrm{C} 17$ oxidation. In this work, we have demonstrated that the $17 \beta$ HSD responsible to transform E2 into E1 is encoded outside the edc cluster since E1 was accumulated in some of the mutant strains where the E2 catabolism was impaired. In this sense, the oecA gene from Sphingomonas sp. KC8, encoding a $17 \beta$ HSD activity, is also located outside cluster II (Chen et al., 2017). 17 $\beta$-HSDs are very common enzymes among bacteria and catalyze the dehydrogenation of different types of $17 \beta$ hydroxysteroids in steroid metabolism. There are some 17-HSDs that transform E2 to E1, homologous to the 17-HSD encoded by EGO55_02230 in N. tardaugens, i.e., OecA from Sphingomonas sp. KC8 encoded by KC8_09390 (20.09\%) and the enzymes from Pseudomonas putida SJTE-1, 3-oxoacyl-ACP reductase, encoded by A210_09220 (34.06\%) (Wang et al., 2018), and 17 $\beta$-HSD, encoded by A210_19955 (37.90\%) (Wang et al., 2019).

The E2 degradation pathway continues with 4-hydroxylation of E1 (Coombe et al., 1966). In Sphingomonas sp. KC8, transcriptomic analyses revealed the upregulation of oec $B$ located within cluster I that encodes a putative flavin-dependent monooxygenase $(\mathrm{OecB})$, and therefore, it was proposed to catalyze the 4-hydroxylation of E1, although this biochemical reaction was not demonstrated (Chen et al., 2017). Although EGO55_13440 of $N$. tardaugens, homologous to oecB, was also upregulated in the E2-grown cells (8.0-fold change), the metabolites accumulated by $\Delta$ Prom, $\triangle \mathrm{OpA}$, and $\Delta \mathrm{OpB}$ mutant strains revealed that E1 hydroxylation activity was encoded in the OpA region. Although we cannot exclude that EGO55_13440 could contribute to E1 hydroxylation in some growing conditions, we looked for a gene coding for this activity within the edc cluster. In this sense, the OpA operon encodes a putative CYP450 hydroxylase (EGO55_13525; edcA) that is upregulated 67.7 -fold on the presence of E2, which was a clear candidate to carry out this biochemical step. CYP450s are enzymes involved in the oxidative degradation of many compounds, and they are particularly well-known for their role in the degradation of environmental toxins and mutagens. In mammals, endogenous estrogens, such as E2 and E1, undergo extensive oxidative metabolism (namely, hydroxylation and keto formation) at various positions, catalyzed by many different CYP450 isoforms present mostly in the liver (Thomas and Potter, 2013). In this work, this hypothesis was confirmed by in vitro assays and using $N$. tardaugens mutants. To the best of our knowledge, the conversion of E1 to 4-OHE1 catalyzed by a bacterial CYP450 has not been described so far. Interestingly, the ecd cluster does not contain genes encoding the required ferredoxin $(\mathrm{Fd})$ and ferredoxin reductase $(\mathrm{FdR})$, suggesting that these proteins are encoded in other loci. There are several genes that can be annotated to encode Fds (EGO55_00615, EGO55_03165, EGO55_03280, EGO55_04875, EGO55_05120, EGO55_08480, EGO55_08640,EGO55_13190) and FdRs (EGO55_01285, EGO55_05820,EGO55_06710,EGO55_09415); 


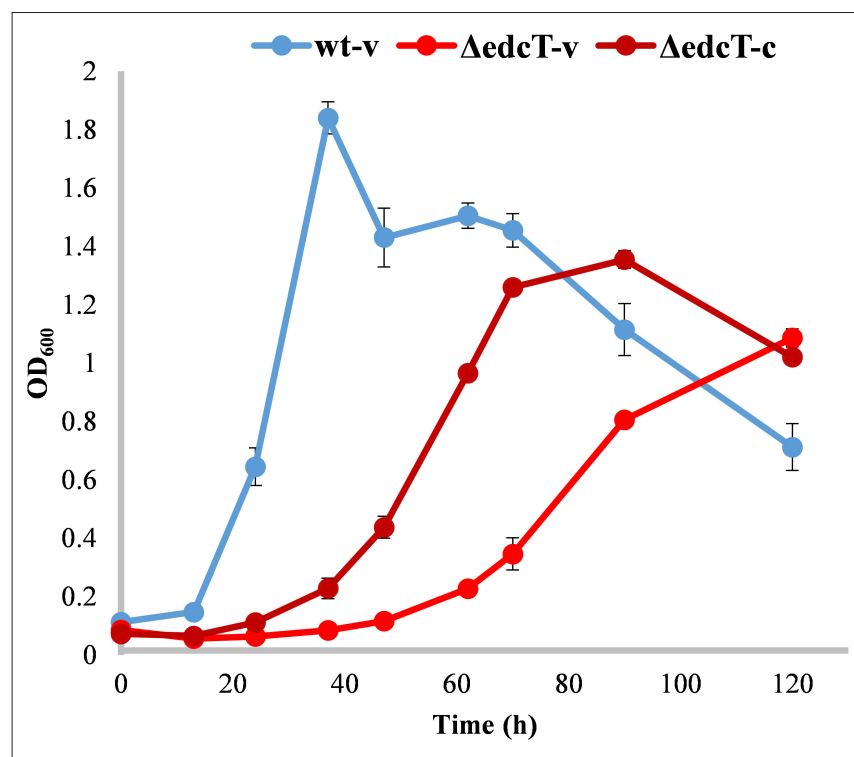

FIGURE 14 | Growth curves $\left(\mathrm{OD}_{600}\right)$ of $N$. tardaugens on M63 minimal medium supplemented with $2 \mathrm{mM}$ E2 of NBRC 16725 and $\Delta$ edcT harboring the pSEVA23PlexA plasmid, (-v), and complemented with the deleted gene, (-c). Data corresponds to biological triplicates and error bars show standard deviation.

however, none of them were overexpressed upon growth on E2 (Table S1). Nevertheless, the number of read counts proves that some of them (i.e., three Fds, EGO55_08480, EGO55_08640 and EGO55_13190, and two FdRs, EGO55_01285 and EGO55_09415) are constitutively expressed and could be part of the redox-partner system of EdcA.

Although EdcA can also hydroxylate E2 in vitro, it does not seem to be the preferred substrate since the activity was very low when compared with that on E1. On the other hand, EdcA was unable to hydroxylate E3 in vitro, since as mentioned above, the presence of the keto group at C17 might be a strong requirement for EdcA activity. In accordance with in vitro results, while none hydroxylated derivatives of E3 have been reported in estrogen-degrading bacteria so far, only one study has reported the detection of 4-OHE2, and it was in resting cell transformations of $\mathrm{E} 2$, in the presence of the metacleavage inhibitor 3-chlorocatechol, by the environmental isolate Sphingomonas sp. ED8 (Kurisu et al., 2010).

The $\Delta$ edcA mutant strain did not grow on E3 and accumulates a compound that presumably corresponds to $16 \alpha-$ OHE1 (Figure 13) suggesting that E3 should be previously oxidized to $16 \alpha-\mathrm{OHE} 1$ by a $17 \beta-\mathrm{HSD}$ coding in the $N$. tardaugens genome. The transient detection of $16 \alpha$-OHE1 during growth on minimal medium with E3 was previously reported in aerobic cultures of the aquifer sand isolate Agromyces sp. LHJ3 strain and identified with authentic standards by LC-MS (Ke et al., 2007).

EcdA activity seems to be a bottleneck of the pathway, in accordance with the widespread transient detection of E1 as intermediate metabolite during E2 degradation. In agreement with this proposal, while the complete transformation of E2 to
E1 has been reported during treatment of waste water spiked with E2 in constructed wetlands and in activated sludge (Ternes et al., 1999; Lee and Liu, 2002; Hashimoto and Murakami, 2009; Dai et al., 2016; Kopperi et al., 2016; Kassotaki et al., 2019), it has been observed that the disappearance/biotransformation of E1 was one order of magnitude lower than that of E2 (Ogunlaja and Parker, 2015).

Subsequently, we have shown that A ring cleavage at $\mathrm{C} 4-\mathrm{C} 5$ is catalyzed by a 4-OHE1 4,5-dioxygenase (EdcB) and the resulting meta-cleavage product appears to be the substrate for the putative indolepyruvate ferredoxin oxidoreductase (EdcC) as it was described before for other estrogen-degrading microorganisms (Coombe et al., 1966; Chen et al., 2017; Wu et al., 2018; Li et al., 2020).

Thereafter, several reactions occur involving the activity of $\beta$-oxidation-like enzymes such as enoyl-CoA hydratases, hydroxyacyl-CoA dehydrogenases, acyl-CoA dehydrogenase, thiolases, and aldolase to form HIP (Figure 1). It is important to notice that the pathway proposed in this work for the degradation of E2 does not contain some of the intermediates detected by other authors, such as compounds Id and Ie (Chen et al., 2018), correlating with IIa and Ia (Coombe et al., 1966), respectively. This pathway was constructed assuming a minimal number of steps according to the genes present in the edc cluster. We cannot exclude that some of these intermediates might result from an alternative opening of ring $B$ just after the formation of 4-norestrogen-5(10)-en-3-oyl-CoA and not at the end of the pathway. Thus, we can envision that the 2ketocyclohexanecarboxyl-CoA hydrolase (EGO55_13545) could act also on this compound generating the compounds Id and Ie, also named IIa and Ia, detected by Chen et al. (2018) and Coombe et al. (1966), respectively. Depending on the specificity of the enzymes and the accumulation of the intermediates during estrogen degradation, it would be possible to find different intermediates that are released to the culture medium as deadend acidic products. These products cannot be incorporated in the pathway since they lose the CoA and they will require not only to be uptaken but also to bind a new CoA molecule to enter the pathway. It is known that the accumulation of a large amount of CoA intermediates within the cell might cause toxic stress (Brass, 1994). Thus, the release of CoA by unspecific thiolases of some pathway intermediates can be used by the cells in order to reduce this stress and recover some CoA for other metabolic functions.

On the other hand, we would like to point out that $\beta$ oxidation-like enzymes have been proven to be responsible for cholate degradation in some Proteobacteria (Barrientos et al., 2015; Holert et al., 2016), and it could be envisioned that these enzymes could be also involved in cholate degradation by $N$. tardaugens, since this strain is able to grow on cholate as a sole carbon and energy source (data not shown). However, our results suggest that cholate and estrogen degradation in $N$. tardaugens is carried out by different pathways. The edc cluster of $N$. tardaugens was not induced in cholate, and $\triangle$ Prom, $\triangle \mathrm{OpA}$, or $\triangle \mathrm{OpB}$ mutant strains were not impaired to grow on cholate as a sole carbon and energy source (data not shown). Furthermore, in Sphingomonas sp. KC8, the genes of cluster II are only involved 
in estrogen degradation, as the strain is unable to use cholate as a sole carbon source (Chen et al., 2017).

The final phase of estrogen degradation that encompasses the HIP degradation pathway follows a series of biochemical reactions involving enzymes similar to those for $\beta$-oxidation of fatty acids that in $N$. tardaugens are encoded in the SD cluster involved in the degradation of TES (Ibero et al., 2019a). Three pieces of evidence support that $N$. tardaugens uses the same gene products to degrade the $\mathrm{C}$ and $\mathrm{D}$ rings of both androgens and estrogens: (i) the SD cluster is upregulated in the presence of both E2 and TES compared with pyruvate; (ii) many of the genes contained in the SD cluster do not have other homologs in the $N$. tardaugens genome; and (iii) the predicted CD-ring degradation genes are highly conserved among different genera of steroidmetabolizing bacteria (Horinouchi et al., 2012, 2019; Holert et al., 2016; Van Hamme et al., 2016; Crowe et al., 2017).

Finally, the transport of steroids has been poorly studied in bacteria, and it was mainly limited to the transport of cholesterol or cholate in Gram-positive bacteria (Mohn et al., 2008; Pandey and Sassetti, 2008; Klepp et al., 2012; Haußmann et al., 2013; García-Fernández et al., 2017). The transport of steroids in Gram-negative bacteria poses a great challenge due to the presence of the outer membrane where a lipopolysaccharide leaflet on the outer surface limits transport through passive diffusion (Plésiat and Nikaido, 1992). Thus, only one study covers this topic in the Gram-negative, anaerobic cholesteroldegrading bacteria, Sterolibacterium denitrificans DSMZ 13999 (Lin et al., 2015). Whereas in Gram-positive bacteria ABC (ATPbinding cassette) transporters are responsible for cholesterol (Pandey and Sassetti, 2008; García-Fernández et al., 2017) and cholate transport (Haußmann et al., 2013), in S. denitrificans, it is a FadL-like system that carries out cholesterol transport (Lin et al., 2015). Thus, our studies on the role of EdcT open a new scenario in this field. The $\Delta$ edcT strain generated in this work showed a significant decrease in growth rate and an increased lag phase with respect to the wild-type strain (Figure 14), suggesting that the TonB-dependent receptor protein could be involved in estrogen uptake in $N$. tardaugens. So far, TBDRs have been proved to be involved in the transport of siderophores, vitamin $\mathrm{B}_{12}$, nickel complexes, carbohydrates (Noinaj et al., 2010), and also of aromatic compounds derived from lignin (Fujita et al., 2019), but to our knowledge, this would be the first time that the TonB-dependent receptor protein is linked to steroid transport.

The results presented in this work and the tools developed to manipulate $N$. tardaugens will pave the way to use this organism as a model to further investigate the steps of estrogen metabolism that render HIP intermediate. The regulatory and transport systems identified in this microorganism will be further studied since they open the possibility for developing regulatory systems and biosensors responding to estrogens. Moreover, taking into account that this bacterium is naturally able to degrade estrogens, androgens, and other steroid molecules, it can be used as an industrial chassis to expand its catabolic properties to degrade other abundant xenobiotic endocrine disruptors. Therefore, our aim for future studies is to investigate the possibility of using $N$. tardaugens to produce biofilters for remediation of contaminated water.

\section{MATERIALS AND METHODS}

\section{Chemicals}

Testosterone (TES), 17 $\beta$-estradiol (E2), estrone (E1), 4hydroxyestrone (4-OHE1), cholate, pyruvate (PYR), chloroform, ethanol, sulfuric acid, and acetonitrile were purchased from Merck KGaA Sigma (Darmstadt, Germany). Randomly methylated $\beta$-cyclodextrin (TRMB-T randomly methylated $\mathrm{BCD}$ ) (CDX) was purchased from Cyclodex (Alachua, United States). Other chemicals and reagents were purchased from Merck KGaA Sigma (Darmstadt, Germany).

\section{Strains and Growth Media}

Bacterial strains and plasmids used in this study are listed in Table 1. N. tardaugens NBRC 16725 (strain ARI-1) was purchased from the Leibniz-Institut DSMZ-type culture collection. This strain and its mutants were cultured at $30^{\circ} \mathrm{C}$ in an orbital shaker at $200 \mathrm{rpm}$. Nutrient broth (NB) (Difco) was used as rich medium to grow this strain. Minimal medium $\mathrm{M} 63\left[\mathrm{KH}_{2} \mathrm{PO}_{4}(136 \mathrm{~g} / \mathrm{L}),\left(\mathrm{NH}_{4}\right)_{2} \mathrm{SO}_{4}(20 \mathrm{~g} / \mathrm{L}), \mathrm{FeSO}_{4} \cdot 7 \mathrm{H}_{2} \mathrm{O}(5\right.$ $\mathrm{mg} / \mathrm{L}), \mathrm{pH} 7.0$ ] was supplemented with $0.39 \mathrm{mM} \mathrm{CaCl}_{2}, 1 \mathrm{mM}$ $\mathrm{MgSO}_{4}$, and the appropriate carbon source concentration. We used a carbon equimolar concentration for each substrate tested. Steroids and PYR stock solutions were prepared in PBS buffer and $70 \mathrm{mM} \mathrm{CDX}$ so the final carbon concentration in the culture was $36 \mathrm{mM}$ in $13.33 \mathrm{mM}$ CDX. E. coli DH10B, E. coli BL21 (DE3), and $E$. coli $\mathrm{HB} 101$ strains were grown at $37^{\circ} \mathrm{C}$ in an orbital shaker at $200 \mathrm{rpm}$ in lysogeny broth (LB) medium (Sambrook and Russell, 2001). The appropriate antibiotics, i.e., chloramphenicol $(34 \mu \mathrm{g} / \mathrm{ml})$, kanamycin $(50 \mu \mathrm{g} / \mathrm{ml})$, or rifampicin $(50 \mu \mathrm{g} / \mathrm{ml})$, were added when needed.

\section{Estrogen Biotransformation Process}

$N$. tardaugens NBRC 16725 and its mutants were cultured at $30^{\circ} \mathrm{C}$ in an orbital shaker at $200 \mathrm{rpm}$ using $\mathrm{NB}$ as rich medium supplemented with $2 \mathrm{mM} \mathrm{E} 2,2 \mathrm{mM} \mathrm{E} 1$, or $1.89 \mathrm{mM} \mathrm{E} 3$. Estrogens were added from a stock solution prepared in CDX as described above.

\section{DNA Manipulation}

DNA manipulation protocols were performed as described elsewhere (Sambrook and Russell, 2001). N. tardaugens genomic DNA was extracted as described before (Ibero et al., 2019b). Plasmid DNA was purified using High Pure Plasmid Isolation Kit (Roche). DNA fragments were purified with QIAquick PCR Purification Kit (Qiagen) or QIAquick Gel Extraction Kit (Qiagen). E. coli cells were transformed using the RbCl method (Sambrook and Russell, 2001) or by electroporation using a Gene Pulser (Bio-Rad) (Wirth et al., 1989). DNA amplification was performed in a Mastercycler Gradient (Eppendorf) using the oligonucleotides listed in Table S2, which were purchased from Sigma (Germany). Phusion High-Fidelity DNA Polymerase (New England Biolabs) was used for cloning amplifications and Taq DNA polymerase (Biotools) for screening. All PCR products were checked by agarose gel electrophoresis and those aimed for cloning were confirmed by DNA sequencing by Secugen S.L. (Spain). Digestion of DNA fragments was done using restriction enzymes (New England Biolabs), and ligation was 
TABLE 1 | Bacterial strains and plasmids used in this study.

\begin{tabular}{|c|c|c|}
\hline Strains & Genotype and characteristics & Source/references \\
\hline NBRC 16725 & Wild-type strain (ARI-1) & Fujii et al., 2003 \\
\hline$\Delta$ Prom & $\begin{array}{l}\text { N. tardaugens NBRC } 16725 \text { where the intergenic region between EGO55_13565 and EGO55_13570 has been } \\
\text { deleted }\end{array}$ & This study \\
\hline$\triangle \mathrm{OpA}$ & N. tardaugens NBRC 16725 where the region EGO55_13565-EGO55_13520 has been deleted & This study \\
\hline$\triangle \mathrm{edcA}$ & N. tardaugens NBRC 16725 AEGO55_13525 & This study \\
\hline$\Delta$ edcB & N. tardaugens NBRC $16725 \Delta E G O 55 \_13570$ & This study \\
\hline$\Delta$ edcC & N. tardaugens NBRC $16725 \Delta E G O 55 \_13580$ & This study \\
\hline$\Delta$ edc $T$ & N. tardaugens NBRC $16725 \Delta E G 055 \_13600$ & This study \\
\hline \multicolumn{3}{|l|}{ E. coli } \\
\hline HB101 & supE44 ara14 galK2 leuB lacY1 $\Delta\left(\right.$ gpt-proA)62 rpsL20 xyl-5 mtl-1 recA13 $\Delta(m c r C-m r r) ~ h s d S 20\left(\mathrm{rB}^{-} \mathrm{mB}^{-}\right) \mathrm{Sm}^{\mathrm{R}}$ & $\begin{array}{l}\text { Sambrook and Russell, } \\
2001\end{array}$ \\
\hline Plasmids & Description & References \\
\hline pRK600 & $\mathrm{Cm}^{r}$ ColE1oriV RP4 oriT; helper plasmid in triparental mattings & Sharma and Signer, 1990 \\
\hline pK18mobsacB & $\mathrm{Km}^{r}$, ColE oriV, Mob+, lacZ $\alpha, s a c B$; vector for allelic exchange homologous recombination mutagenesis & Schafer et al., 1994 \\
\hline pK18Prom & $\begin{array}{l}\text { pK18mobsacB derivative containing fragments UP-Prom and DOWN-Prom used for } \triangle \text { Prom mutant construction, } \\
\mathrm{Km}^{\mathrm{R}}\end{array}$ & This study \\
\hline pK180pA & $\begin{array}{l}\text { pK18mobsacB derivative containing fragments UP-OpA and DOWN-OpA used for } \triangle \mathrm{OpA} \text { mutant construction, } \\
\mathrm{Km}^{\mathrm{R}}\end{array}$ & This study \\
\hline pK180pB & $\begin{array}{l}\text { pK18mobsacB derivative containing fragments UP-OpB and DOWN-OpB used for } \triangle \mathrm{OpB} \text { mutant construction, } \\
\mathrm{Km}^{\mathrm{R}}\end{array}$ & This study \\
\hline pSEVA23edcA & pSEVA237PlexA where the gfp gene was replaced by EGO55_13525 & This study \\
\hline pSEVA23edcB & pSEVA237PlexA where the gfp gene was replaced by EGO55_13570 & This study \\
\hline pSEVA23edcC & pSEVA237PlexA where the gfp gene was replaced by EGO55_13580 & This study \\
\hline pSEVA23edcT & pSEVA237PlexA where the gfp gene was replaced by EGO55_13600 & This study \\
\hline pSEVA237PbPlexA & pSEVA237PlexA where the promoter region $P_{b}$ was cloned & This study \\
\hline pSEVA237Pb-edcA & pSEVA237Pb containing the EGO55_13520 gene & This study \\
\hline pSEVA237Pb-edcAB & pSEVA237Pb containing the EGO55_13520 and EGO55_13570 genes & This study \\
\hline pSEVA237Pb-edcABC & pSEVA237Pb containing the EGO55_13525, EGO55_13570, and EGO55_13580 genes & This study \\
\hline pET-29a(+) & Cloning and expression vector, $\mathrm{Km}^{r}$, oriColE1, $P_{T 7}$ promoter & Novagen \\
\hline pET29edcA & pET-29 containing the EGO55_13525 gene & This study \\
\hline
\end{tabular}

performed with Instant Sticky-end Ligase Master Mix (New England Biolabs).

\section{RNA Extraction}

Total RNA of $N$. tardaugens cells was extracted from cultures grown on minimal medium with $20 \mathrm{mM}$ CDX and E2 or PYR as carbon sources as described previously (Ibero et al., 2019a). Briefly, cells where harvested in mid exponential phase $\left(\mathrm{OD}_{600}\right.$ 0.6) and stored at $-80^{\circ} \mathrm{C}$. Pellets where thawed and cells were lysed in $400 \mu \mathrm{l}$ TE buffer $(10 \mathrm{mM}$ Tris$\mathrm{HCl}, 1 \mathrm{mM}$ EDTA, pH 7.5) containing lysozyme (50 mg/ml) following three freezing-thawing cycles. High Pure Isolation Kit (Roche), followed by DNA-free DNA Removal Kit (Invitrogen) treatment, was used to obtained pure RNA. Purity and 
concentration were measured in a ND1000 spectrophotometer (Nanodrop Technologies).

\section{Transcriptomic Analysis (RNA-Seq)}

RNA-seq was done in Macrogen Korea. Total RNA integrity was checked using an Agilent Technologies 2100 Bioanalyzer. Ribosomal RNA was removed from the total RNA with Ribo-Zero rRNA Removal Kit to later construct a 100-bp paired-end library using TruSeq RNA Sample Prep Kit v2 that was quality-checked in an Agilent Technologies 2100 Bioanalyzer using a DNA 1000 chip. Library sequencing was performed in a HiSeq 30004000 (Illumina) using TruSeq 30004000 SBS Kit v3 as reagent. Bioinformatics analyses were performed by the Bioinformatics and Biostatistics Service of the Center for Biological Research Margarita Salas (CIBMSCSIC). Raw read data quality was checked using FastQC and trimmed with Trimmomatic. Trimmed reads were mapped against the genome sequence of $N$. tardaugens (accession number CP034179) using Bowtie2, and expression quantification was done using HTSeq-count. An average of 69 million raw sequencing reads (approximately 6.9 billion base pairs; average $1,600 \times$ genome coverage per sample) were generated from samples from two independent experiments in the presence of PYR or E2, each with three biological replicates. After trimming the raw sequence reads, an average 25.3 million high-quality clean reads were mapped to the $N$. tardaugens reference genome and between 74.4 and 59.3\% were uniquely mapped. Differential expression analysis was done using Deseq2. The dissimilarity matrix shown in the heatmap was obtained with the Euclidean distance, and the cluster analysis was performed with Ward's minimum variance method. Bioinformatics analysis software was used with default settings. Raw read data obtained from the three replicates of the transcriptome of the strain grown on PYR and E2 have been deposited in the Sequence Read Archive (SRA) database of the National Center for Biotechnology Information (NCBI) under accession numbers SRR9027780, SRR9027781, and SRR9027779 (Bioproject PRJNA541800) and in the European Nucleotide Archive (ENA) database of the European Bioinformatics Institute (EMBL-EBI) under accession number ERP122552 (BioprojectPRJEB39081), respectively.

\section{Construction of $\boldsymbol{N}$. tardaugens Knockout Strains}

The knockout strains were constructed by double homologous recombination using the suicide vector pK18mobsacB (Schafer et al., 1994) as described before (Ibero et al., 2019a). N. tardaugens genomic DNA was used as template to amplify two fragments of $\approx 700$ bp containing the upstream and downstream regions of the gene to delete UP and DOWN fragments (Table 1 and Table S2), respectively. The fragments were digested with the appropriate restriction enzymes and cloned in the unique sites of the plasmid. The ligation product was transformed into E. coli DH10Bcompetent cells, and once recombinant candidates were PCRchecked, the cloned region was confirmed by sequencing. The plasmids were transformed by triparental conjugation (Herrero et al., 1990) into $N$. tardaugens $\mathrm{Rf}^{\mathrm{R}}$ as recipient strain using
E. coli HB101 (pRK600) (Sharma and Signer, 1990) as helper and E. coli $\mathrm{DH} 10 \mathrm{~B}$, harboring the corresponding vector, as donor. To prepare the recipient strain, $10 \mathrm{ml}$ of late exponential phase cultures were centrifuged at $13,000 \mathrm{rpm}$ for $1 \mathrm{~min}$, and the pellet was washed with one volume of sterile $0.85 \% \mathrm{NaCl}$ solution. The cells were centrifuged again and the pellet was resuspended to a final volume of $100 \mu \mathrm{l}$ of $0.85 \% \mathrm{NaCl}$ solution. One milliliter of overnight cultures of donor and helper strains were centrifuged at $13,000 \mathrm{rpm}$ for $1 \mathrm{~min}$, and the pellet was washed in $500 \mu \mathrm{l}$ of sterile $0.85 \% \mathrm{NaCl}$ solution. Fifty microliters of each strain was mixed and pipetted to a $0.22-\mu l$ filter disc placed on the NB plate. The plate was incubated overnight at $30^{\circ} \mathrm{C}$. The next day, the filter mating disks were collected in a $1.5-\mathrm{ml}$ tube with $1 \mathrm{ml}$ of a sterile $0.85 \% \mathrm{NaCl}$ solution and vortexed thoroughly to detach the cells from the filter. Afterwards, $100 \mu \mathrm{l}$ and the rest of the cells were plated on NB plates containing selective antibiotic kanamycin $(10 \mu \mathrm{g} / \mathrm{ml})$ and rifampicin $(50 \mu \mathrm{g} / \mathrm{ml})$ and screened by PCR using appropriate primers (Table S2). Selected candidates were grown up to stationary phase $(\approx 48 \mathrm{~h})$ in NB medium and then plated in NB supplemented with $5 \%$ sucrose. The clones that are resistant to sucrose and sensitive to kanamycin were checked by PCR using external primers, and the amplicon was sequenced to confirm the second crossover event.

\section{Complementation of $\boldsymbol{N}$. tardaugens Knockout Strains}

The mutant strains were transformed with a pSEVA23 plasmid harboring the corresponding deleted gene under the expression control of $P_{\text {lexA }}$ constitutive promoter (Fernández et al., 2014; Table 1) using triparental conjugation, following the same protocol as used to construct $N$. tardaugens knockout strains. The $P_{b}$ native promoter from $N$. tardaugens was also used for gene expression in pSEVA23 plasmid and corresponds to a region of $300 \mathrm{pb}$ upstream of EGO55_13570 gene which includes the intergenic region of the edc cluster, where the putative promoters of the cluster are located.

\section{Organic Phase Extraction and Thin Layer Chromatographic Analysis}

The presence of steroidal compounds in culture media and enzymatic assay mixtures was determined after organic solvent extraction by thin layer chromatographic (TLC) analysis as described before (Ibero et al., 2019a). Two volumes of chloroform were added, and the mixture was vortexed for $30 \mathrm{~s}$ and centrifuged for $1 \mathrm{~min}$ at 13,000 rpm in an Eppendorf microcentrifuge. The organic phase was extracted and dried. The dried sample was dissolved in $100 \mu \mathrm{l}$ of acetonitrile and analyzed by thin layer chromatography (TLC). For TLC analysis, $10 \mu \mathrm{l}$ of the standards and the samples dissolved in acetonitrile were spotted in silica gel plates (TLC Silicagel $60 \mathrm{~F}_{2} 54$, Merck Millipore), and $n$-hexane:ethyl acetate $(10: 4 \mathrm{v} / \mathrm{v})$ was used as a developing system. Steroid products were visualized by UV and revealed by spraying $20 \%$ (v/v) sulfuric acid and heating at $120^{\circ} \mathrm{C}$. 
TABLE 2 | LC-MS analysis of metabolites involved in estrogen catabolism in N. tardaugens.

\begin{tabular}{|c|c|c|c|c|}
\hline Compound name & LC-MS RT (min) & Molecular formula & $\begin{array}{l}\text { Dominant ion } \\
\text { peaks }\end{array}$ & $\begin{array}{l}\text { Identified product } \\
\text { ions }\end{array}$ \\
\hline E2 & 18.39 & $\mathrm{C}_{18} \mathrm{H}_{24} \mathrm{O}_{2}$ & 255.15 & {$\left[\mathrm{M}-\mathrm{H}_{2} \mathrm{O}+\mathrm{H}\right]^{+}$} \\
\hline E1 & 22.14 & $\mathrm{C}_{18} \mathrm{H}_{22} \mathrm{O}_{2}$ & 271.19 & {$[\mathrm{M}+\mathrm{H}]^{+}$} \\
\hline 4-OHE1 & 17.06 & $\mathrm{C}_{18} \mathrm{H}_{22} \mathrm{O}_{3}$ & 287.27 & {$[\mathrm{M}+\mathrm{H}]^{+}$} \\
\hline Pyridinestrone acid & 3.28 & $\mathrm{C}_{18} \mathrm{H}_{21} \mathrm{O}_{3} \mathrm{~N}$ & 300.21 & {$[\mathrm{M}+\mathrm{H}]^{+}$} \\
\hline $\begin{array}{l}\text { 4-Norestrogen-5(10)-en-3-oic acid } \\
\text { (M5 deconjugated) }\end{array}$ & 12.76 & $\mathrm{C}_{17} \mathrm{H}_{22} \mathrm{O}_{4}$ & 273.32 & {$\left[\mathrm{M}-\mathrm{H}_{2} \mathrm{O}+\mathrm{H}\right]^{+}$} \\
\hline E3 & 5.55 & $\mathrm{C}_{18} \mathrm{H}_{24} \mathrm{O}_{3}$ & 271.19 & {$\left[\mathrm{M}-\mathrm{H}_{2} \mathrm{O}+\mathrm{H}\right]^{+}$} \\
\hline 16-keto-E2/16 $\alpha-\mathrm{OH}-\mathrm{E} 1$ & 9.65 & $\mathrm{C}_{18} \mathrm{H}_{22} \mathrm{O}_{3}$ & 287.31 & {$[\mathrm{M}+\mathrm{H}]^{+}$} \\
\hline 4-OH-16-keto-E2/4-OH-16 -OH-E1 & 5.79 & $\mathrm{C}_{18} \mathrm{H}_{22} \mathrm{O} 4$ & 303.28 & {$[\mathrm{M}+\mathrm{H}]^{+}$} \\
\hline
\end{tabular}

\section{HPLC-MS and GC-MS Analysis}

Detection and identification of different steroids extracted from cultures (Table 2) and from the hydroxylation reaction carried out with EdcA was carried using high-efficiency liquid chromatography coupled to a photodiode array detector and mass spectroscopy (HPLC-DAD-MS) using liquid chromatography equipment (Surveyor Plus LC) equipped with automatic injector coupled to a diode array detector (DAD) and with an ion trap (LXQ) equipped with a source of electrospray ionization (ESI), all supplied by Thermo Electron (San Jose, CA, United States). The data was processed with the Xcalibur program (Thermo Fisher Scientific, San Jose, CA, United States). Chromatographic separation was performed using a Mediterranea Sea C18 reverse phase column $(150 \times$ $4.6 \mathrm{~mm}$ internal diameter, $5 \mu \mathrm{m}$ particle size) (Teknokroma, Barcelona, Spain). Samples were eluted with a $1 \mathrm{ml} \mathrm{min}^{-1}$ gradient flow (solvent $\mathrm{A}, \mathrm{H}_{2} \mathrm{O}+0.1 \%$ formic acid; solvent $\mathrm{B}$, $\mathrm{CH}_{3} \mathrm{CN}+0.1 \%$ formic acid) starting with $30 \% \mathrm{~B}$ for $5 \mathrm{~min}$ and increasing solvent up to $55 \%$ B for 20 min. The solvent B \% was then increased to $100 \%$ in $5 \mathrm{~min}$. The elution was maintained at $100 \% \mathrm{~B}$ for $5 \mathrm{~min}$ and then reduced again to $30 \% \mathrm{~B}$ in $5 \mathrm{~min}$, followed by equilibration of the column for $5 \mathrm{~min}$ prior to injection of the next sample.

The enzymatic reactions were monitored by HPLC using an Agilent Series 1200 HPLC system and the same reverse phase $\mathrm{C} 18$ column. The samples were eluted isocratically at a flow rate of $1 \mathrm{ml} \mathrm{min}{ }^{-1}$ (solvent $\mathrm{A}, \mathrm{H}_{2} \mathrm{O}+0.1 \% \mathrm{FA}$; solvent $\mathrm{B}, \mathrm{CH}_{3} \mathrm{CN}$ $+0.1 \% \mathrm{FA}$ ) with a gradient starting at $60 \% \mathrm{~B}$ up to $2 \mathrm{~min}$, and the solvents ramped up to $100 \% \mathrm{~B}$ over $9 \mathrm{~min}$. The elution was maintained at $100 \%$ B for $2 \mathrm{~min}$ and then ramped back to $60 \% \mathrm{~B}$ within $2 \mathrm{~min}$, followed by equilibration at the same composition for $2 \mathrm{~min}$ before the next run. The elution was monitored at $240 \mathrm{~nm}$. When required, the enzymatic assays were monitored by GC-MS. The chloroform extracted fraction was concentrated by evaporation, and the trimethylsilyl ether derivatives were formed by reaction with $50 \mu \mathrm{l}$ of BSTFA and $50 \mu \mathrm{l}$ of pyridine and heating at $60^{\circ} \mathrm{C}$ for $45 \mathrm{~min}$. Calibration standards were derivatized in the same way. The GC/MS analysis was carried out using an Agilent 7890A gas chromatograph coupled to an Agilent 5975C mass detector (Agilent Technologies, Palo Alto, CA, United States). Mass spectra were recorded in electron impact (EI) mode at $70 \mathrm{eV}$ within the $\mathrm{m} / z$ range $50-550$. The chromatograph was equipped with a $30-\mathrm{m} \times 0.25-\mathrm{mm}$ i.d. capillary column ( $0.25 \mathrm{~m}$ film thickness) HP-5MS (5\% diphenyl 95\% dimethylpolysiloxane from Agilent Technologies). Working conditions in the sample were as follows: split ratio 20:1, injector temperature $320^{\circ} \mathrm{C}$, and column temperature $240^{\circ} \mathrm{C}$ for $3 \mathrm{~min}$, then heated to $320^{\circ} \mathrm{C}$ at $5^{\circ} \mathrm{C} \mathrm{min}^{-1}$. EI mass spectra and retention data were used to assess the identity of compounds by comparing them with those of standards in the NIST Mass Spectral Database and commercial standards.

\section{Cloning and Expression of CYP450}

The DNA fragment containing the EGO55_13525 gene was amplified by PCR with primers specified in Table S2, digested with the corresponding restriction enzymes and then ligated into the pET29a vector yielding pET29-edcA. Electrocompetent cells of $E$. coli BL21 (DE3) were transformed with pETedcA. The resulting strain E. coli BL21 (DE3) (pETedcA) was cultured in $50 \mathrm{ml}$ LB containing kanamycin up to an $\mathrm{OD}_{600}$ of $0.5-0.8$, and gene expression was induced with $0.2 \mathrm{mM}$ IPTG and aminolevulinic acid. After $3 \mathrm{~h}$ of induction, the cells were harvested, washed with $0.85 \%$ saline solution, and resuspended in $20 \mathrm{mM}$ Tris- $\mathrm{HCl}$ ( $\mathrm{pH}$ 8.0). Cells were lysed by sonication using a Branson sonicator applying three cycles of 30-s bursts at maximum power alternated with $30 \mathrm{~s}$ cooling in ice. Soluble fraction was separated by centrifugation in a Sorvall Linx 6000 (SS-34 rotor, $15 \mathrm{~min}$ at $4^{\circ} \mathrm{C}$ and $14,000 \mathrm{rpm}$ ), and protein concentration was calculated by the Bradford method (Bradford, 1976). The overproduction of EdcA in the soluble fraction of the crude extract was checked by SDS-polyacrylamide gel electrophoresis.

\section{Enzymatic Assay of E1-Hydroxylase Activity}

The enzymatic activity of CYP450 was examined in vitro using heterologous electron donor partners: spinach ferredoxin and ferredoxin reductase and a NADPH regenerating system, as described previously (García-Fernández et al., 2013). Reactions were carried out in glass tubes at ambient temperature in a volume of $200 \mu \mathrm{l}$. Estrogen stock solutions $(10 \mathrm{mM})$ were 
prepared in methanol. Crude extract (70 $\mu \mathrm{g}$ of protein) was pre-incubated $5 \mathrm{~min}$ with $100 \mu \mathrm{M}$ of substrate in $50 \mathrm{mM}$ sodium phosphate buffer ( $\mathrm{pH} 7.5$ ) containing $0.45 \%(\mathrm{w} / \mathrm{v})$ $\mathrm{M} \beta \mathrm{CD}$ and $10 \mathrm{mM} \mathrm{MgCl}_{2}$. Reactions were initiated by adding $0.3 \mathrm{mM}$ NADPH, $1 \mu \mathrm{M}$ spinach ferredoxin, $0.2 \mathrm{U} \mathrm{ml}^{-1}$ spinach ferredoxin-NADP ${ }^{+}$reductase, $0.1 \mathrm{mg} \mathrm{ml}^{-1}$ bovine liver catalase, and an NADPH-regenerating system consisting of $0.4 \mathrm{U} \mathrm{ml}^{-1}$ glucose 6-phosphate dehydrogenase and $5 \mathrm{mM}$ glucose 6phosphate. Aliquots of $50 \mu \mathrm{l}$ were taken at 0,5 , and $30 \mathrm{~min}$ and quenched with $150 \mu \mathrm{l}$ of acetonitrile containing $0.1 \%$ formic acid (FA). The reaction mixtures were centrifuged at $10,000 \times g$ for $4 \mathrm{~min}$.

\section{In silico Analysis}

Protein sequence comparisons where made using the Standard Protein Basic Local Alignment Search Tool (BLASTp) (Altschul et al., 1990). The HMG-CoA synthetases sequences were collected from the public databases. The sequences were aligned by Clustal Omega built on Geneious Prime (available from http://www.geneious.com). The neighbor-joining analysis was performed using MEGA7 (Kumar et al., 2018).

\section{CONCLUSION}

The present study constitutes a step forward in understanding estrogen catabolism in bacteria. The transcriptome of $N$. tardaugens cells grown on E2 revealed a conserved estrogen degradation gene cluster, named edc. Genetic tools were applied in this estrogen-degrading bacterium to delete and complement some of the genes of the edc cluster to determine their precise role. These tools will allow elucidating the complete biochemical reactions of estrogen degradation in the near future. One of the main findings has been that, as it occurs in mammals, a CYP450 encoded by the edcA gene performs the 4hydroxylation of estrone in this strain. Subsequent degradation steps, like A-ring cleavage of 4 -OHE1 by a 4,5-dioxygenase $(\mathrm{EdcB})$, and decarboxylation of the resulting alkylic chain by an indolepyruvate ferredoxin oxidoreductase (EdcC), have been confirmed in vivo. Moreover, we have linked steroid uptake to a TonB-dependent receptor protein (EdcT) conserved among estrogen degraders that appears to be necessary to achieve efficient estrogen mineralization in $N$. tardaugens.

\section{REFERENCES}

Altschul, S. F., Gish, W., Miller, W., Myers, E. W., and Lipman, D. J. (1990). Basic local alignment search tool. J. Mol. Biol. 215, 403-410. doi: 10.1016/S0022-2836(05)80360-2

Barbosa, M. O., Moreira, N. F. F., Ribeiro, A. R., Pereira, M. F. R., and Silva, A. M. T. (2016). Occurrence and removal of organic micropollutants: an overview of the watch list of EU decision 2015/495. Water Res. 94, 257-279. doi: 10.1016/j.watres.2016.02.047

Barrientos, Á., Merino, E., Casabon, I., Rodríguez, J., Crowe, A. M., Holert, J., et al. (2015). Functional analyses of three acyl-CoA synthetases involved in bile acid degradation in Pseudomonas putida DOC21. Environ. Microbiol. 17, 47-63. doi: 10.1111/1462-2920.12395

\section{DATA AVAILABILITY STATEMENT}

The datasets generated for this study can be found in Sequence Read Archive (SRA) 26 database of the National Center for Biotechnology Information (NCBI) under accession numbers SRR9027780, SRR9027781, SRR9027779 (Bioproject PRJNA541800), and in the European Nucleotide Archive (ENA) database of the European Bioinformatics Institute (EMBL-EBI) under accession number ERP122552 (BioprojectPRJEB39081).

\section{AUTHOR CONTRIBUTIONS}

JI carried out the experiments and helped in drafting the manuscript. JG and BG conceived and coordinated the study and drafted the manuscript. JG, JI, BG, and VR-B participated in analyzing the data. All authors read, reviewed, and approved the final manuscript.

\section{FUNDING}

This work was supported by the Ramon Areces Foundation (ELISA project).

\section{ACKNOWLEDGMENTS}

The bioinformatics support of the Bioinformatics and Biostatistics Service of CIB particularly Guillermo Padilla Alonso is greatly appreciated. The technical work of A. Valencia is greatly appreciated. We are deeply indebted to the Protein Chemistry service and GC-MS services of CIB for chromatographic technical and data interpretation support. We want to thank to Dr. de Eugenio for the support on HPLC. We acknowledge the support of the publication fee by the CSIC Open Access Publication Support Initiative through its Unit of Information Resources for Research (URICI). We also acknowledge the financial support provided by the Ramón Areces Foundation.

\section{SUPPLEMENTARY MATERIAL}

The Supplementary Material for this article can be found online at: https://www.frontiersin.org/articles/10.3389/fmicb. 2020.588300/full\#supplementary-material

Bradford, M. M. (1976). A rapid and sensitive method for the quantitation of microgram quantities of protein utilizing the principle of protein-dye binding. Anal. Biochem. 72, 248-254. doi: 10.1016/0003-2697(76)90527-3

Brass, E. P. (1994). Overview of coenzyme A metabolism and its role in cellular toxicity. Chem. Biol. Interact. 90, 203-214. doi: 10.1016/0009-2797(94)90010-8

Casabon, I., Crowe, A. M., Liu, J., and Eltis, L. D. (2013). FadD3 is an acylCoA synthetase that initiates catabolism of cholesterol rings $\mathrm{C}$ and $\mathrm{D}$ in actinobacteria. Mol. Microbiol. 87, 269-283. doi: 10.1111/mmi.12095

Chen, Y.-L., Fu, H.-Y., Lee, T.-H., Shih, C.-J., Huang, L., Wang, Y.-S., et al. (2018). Estrogen degraders and estrogen degradation pathway identified in an activated sludge. Appl. Environ. Microbiol. 84, e00001-18. doi: 10.1128/AEM.00001-18

Chen, Y.-L. L., Fu, H.-Y., Lee, T.-H. H., Shih, C.-J. J., Huang, L., Wang, Y.S., et al. (2017). Biochemical mechanisms and catabolic enzymes involved 
in bacterial estrogen degradation pathways. Cell Chem. Biol. 24, 712-724.e7. doi: 10.1016/j.chembiol.2017.05.012

Coombe, R. G., Tsong, Y. Y., Hamilton, P. B., and Sih, C. J. (1966). Mechanisms of steroid oxidation by microorganisms. X. Oxidative cleavage of estrone. J. Biol. Chem. 241, 1587-1595.

Crowe, A. M., Casabon, I., Brown, K. L., Liu, J., Lian, J., Rogalski, J. C., et al. (2017). Catabolism of the last two steroid rings in Mycobacterium tuberculosis and other bacteria. Mbio 8, e00321-e00317. doi: 10.1128/mBio.00321-17

Dai, Y. N., Dan, A., Yang, Y., Tam, N. F. Y., Tai, Y. P., and Tang, X. Y. (2016). Factors affecting behavior of phenolic endocrine disruptors, estrone and estradiol, in constructed wetlands for domestic sewage treatment. Environ. Sci. Technol. 50, 11844-11852. doi: 10.1021/acs.est.6b02026

Fahrbach, M., Kuever, J., Meinke, R., Kampfer, P., and Hollender, J. (2006). Denitratisoma oestradiolicum gen. nov., sp. nov., a 17beta-oestradiol-degrading, denitrifying Betaproteobacterium. Int. J. Syst. Evol. Microbiol. 56, 1547-1552. doi: $10.1099 /$ ijs.0.63672-0

Fernández, H., Prandoni, N., Fernández-Pascual, M., Fajardo, S., Morcillo, C., Díaz, E., et al. (2014). Azoarcus sp. CIB, an anaerobic biodegrader of aromatic compounds shows an endophytic lifestyle. PLoS ONE 9:e110771. doi: 10.1371/journal.pone.0110771

Fujii, K., Kikuchi, S., Satomi, M., Ushio-Sata, N., and Morita, N. (2002). Degradation of $17 \beta$-estradiol by a gram-negative bacterium isolated from activated sludge in a sewage treatment plant in Tokyo, Japan. Appl. Environ. Microbiol. 68, 2057-2060. doi: 10.1128/AEM.68.4.2057-2060.2002

Fujii, K., Satomi, M., Morita, N., Motomura, T., Tanaka, T., and Kikuchi, S. (2003). Novosphingobium tardaugens sp. nov., an oestradiol-degrading bacterium isolated from activated sludge of a sewage treatment plant in Tokyo. Int. J. Syst. Evol. Microbiol. 53, 47-52. doi: 10.1099/ijs.0.02301-0

Fujita, M., Mori, K., Hara, H., Hishiyama, S., Kamimura, N., and Masai, E. (2019). A TonB-dependent receptor constitutes the outer membrane transport system for a lignin-derived aromatic compound. Commun. Biol. 2:432. doi: 10.1038/s42003-019-0676-z

García-Fernández, E., Frank, D. J., Galán, B., Kells, P. M., Podust, L. M., García, J. L., et al. (2013). A highly conserved mycobacterial cholesterol catabolic pathway. Environ. Microbiol. 15, 2342-2359. doi: 10.1111/1462-2920.12108

García-Fernández, J., Papavinasasundaram, K., Galán, B., Sassetti, C. M., and García, J. L. (2017). Molecular and functional analysis of the mce4 operon in Mycobacterium smegmatis. Environ. Microbiol. 19, 3689-3699. doi: 10.1111/1462-2920.13869

Hashimoto, T., and Murakami, T. (2009). Removal and degradation characteristics of natural and synthetic estrogens by activated sludge in batch experiments. Water Res. 43, 573-582. doi: 10.1016/j.watres.2008.10.051

Haußmann, U., Wolters, D. A., Fränzel, B., Eltis, L. D., and Poetsch, A. (2013). Physiological adaptation of the Rhodococcus jostii RHAl membrane proteome to steroids as growth substrates. J. Proteome Res. 12, 1188-1198. doi: $10.1021 /$ pr300816n

He, P., and Moran, G. R. (2011). Structural and mechanistic comparisons of the metal-binding members of the vicinal oxygen chelate (VOC) superfamily. J. Inorg. Biochem. 105, 1259-1272. doi: 10.1016/j.jinorgbio.2011.06.006

Heath, R. J., and Rock, C. O. (2002). The claisen condensation in biology. Nat. Prod. Rep. 19, 581-596. doi: 10.1039/b110221b

Herrero, M., De Lorenzo, V., and Timmis, K. N. (1990). Transposon vectors containing non-antibiotic resistance selection markers for cloning and stable chromosomal insertion of foreign genes in gram-negative bacteria. J. Bacteriol. 172, 6557-6567. doi: 10.1128/JB.172.11.6557-6567.1990

Holert, J., Yücel, O., Jagmann, N., Prestel, A., Möller, H. M., and Philipp, B. (2016). Identification of bypass reactions leading to the formation of one central steroid degradation intermediate in metabolism of different bile salts in Pseudomonas sp. strain Chol1. Environ. Microbiol. 18, 3373-3389. doi: $10.1111 / 1462-2920.13192$

Horinouchi, M., Hayashi, T., Koshino, H., and Kudo, T. (2006). ORF18-disrupted mutant of Comamonas testosteroni TA441 accumulates significant amounts of 9,17-dioxo-1,2,3,4,10,19-hexanorandrostan-5-oic acid and its derivatives after incubation with steroids. J. Steroid Biochem. Mol. Biol. 101, 78-84. doi: 10.1016/j.jsbmb.2006.06.006

Horinouchi, M., Hayashi, T., and Kudo, T. (2012). Steroid degradation in Comamonas testosteroni. J. Steroid Biochem. Mol. Biol. 129, 4-14. doi: $10.1016 /$ j.jsbmb.2010.10.008
Horinouchi, M., Koshino, H., Malon, M., Hirota, H., and Hayashi, T. (2019). Steroid degradation in Comamonas testosteroni TA441: identification of the entire $\beta$-oxidation cycle of the cleaved B ring. Appl. Environ. Microbiol. 85, e01204-e01219. doi: 10.1128/AEM.01204-19

Ibero, J., Galán, B., Díaz, E., and García, J. L. (2019a). Testosterone degradative pathway of Novosphingobium tardaugens. Genes 10:871. doi: 10.3390/genes10110871

Ibero, J., Sanz, D., Galán, B., Díaz, E., and García, J. L. (2019b). High-quality whole-genome sequence of an estradiol-degrading strain, Novosphingobium tardaugens NBRC 16725. Microb. Resour. Annouc. 8, e01715-e01718. doi: 10.1128/MRA.01715-18

Kassotaki, E., Pijuan, M., Rodriguez-Roda, I., and Buttiglieri, G. (2019). Comparative assessment of endocrine disrupting compounds removal in heterotrophic and enriched nitrifying biomass. Chemosphere 217, 659-668. doi: 10.1016/j.chemosphere.2018.11.012

Ke, J., Zhuang, W., Gin, K. Y. H., Reinhard, M., Hoon, L. T., and Tay, J. H. (2007). Characterization of estrogen-degrading bacteria isolated from an artificial sandy aquifer with ultrafiltered secondary effluent as the medium. Appl. Microbiol. Biotechnol. 75, 1163-1171. doi: 10.1007/s00253-007-0923-y

Klepp, L. I., Forrellad, M. A., Osella, A. V., Blanco, F. C., Stella, E. J., Bianco, M. V., et al. (2012). Impact of the deletion of the six mce operons in Mycobacterium smegmatis. Microbes Infect. 14, 590-599. doi: 10.1016/j.micinf.2012.01.007

Kletzin, A., and Adams, M. W. W. (1996). Molecular and phylogenetic characterization of pyruvate and 2-ketoisovalerate ferredoxin oxidoreductases from Pyrococcus furiosus and pyruvate ferredoxin oxidoreductase from Thermotoga maritima. J. Bacteriol. 178, 248-257. doi: 10.1128/JB.178.1.248-257.1996

Kopperi, M., Parshintsev, J., Ruiz-Jiménez, J., and Riekkola, M. L. (2016). Nontargeted evaluation of the fate of steroids during wastewater treatment by comprehensive two-dimensional gas chromatography-timeof-flight mass spectrometry. Environ. Sci. Pollut. Res. 23, 17008-17017. doi: 10.1007/s11356-016-6800-4

Kumar, S., Stecher, G., Li, M., Knyaz, C., and Tamura, K. (2018). MEGA X: molecular evolutionary genetics analysis across computing platforms. Mol. Biol. Evol. 35, 1547-1549. doi: 10.1093/molbev/msy096

Kurisu, F., Ogura, M., Saitoh, S., Yamazoe, A., and Yagi, O. (2010). Degradation of natural estrogen and identification of the metabolites produced by soil isolates of Rhodococcus sp. and Sphingomonas sp. J. Biosci. Bioeng. 109, 576-582. doi: 10.1016/j.jbiosc.2009.11.006

Lee, H. B., and Liu, D. (2002). Degradation of $17 \beta$-estradiol and its metabolities by sewage bacteria. Water. Air. Soil Pollut. 134, 353-368. doi: 10.1023/A:1014117329403

Li, S., Liu, J., Williams, M. A., Ling, W., Sun, K., Lu, C., et al. (2020). Metabolism of $17 \beta$-estradiol by Novosphingobium sp. ES2-1 as probed via HRMS combined with 13C3-labeling. J. Hazard. Mater. 389:121875. doi: 10.1016/j.jhazmat.2019.121875

Lin, C. W., Wang, P. H., Ismail, W., Tsai, Y. W., Nayal, A., Yang, C. Y., et al. (2015). Substrate uptake and subcellular compartmentation of anoxic cholesterol catabolism in Sterolibacterium denitrificans. J. Biol. Chem. 290, 1155-1169. doi: 10.1074/jbc.M114.603779

Lønning, P. E., Haynes, B. P., Straume, A. H., Dunbier, A., Helle, H., Knappskog, S., et al. (2011). Exploring breast cancer estrogen disposition: the basis for endocrine manipulation. Clin. Cancer Res. 17, 4948-4958. doi: 10.1158/1078-0432.CCR-11-0043

Mai, X., and Adams, M. W. W. (1994). Indolepyruvate ferredoxin oxidoreductase from the hyperthermophilic archaeon Pyrococcus furiosus. A new enzyme involved in peptide fermentation. J. Biol. Chem. 269, 16726-16732.

Mohn, W. W., Van Der Geize, R., Stewart, G. R., Okamoto, S., Liu, J., Dijkhuizen, L., et al. (2008). The actinobacterial mce4 locus encodes a steroid transporter. J. Biol. Chem. 283, 35368-35374. doi: 10.1074/jbc.M8054 96200

Noinaj, N., Guillier, M., Barnard, T. J., and Buchanan, S. K. (2010). TonB-dependent transporters: regulation, structure, and function. Annu. Rev. Microbiol. 64, 43-60. doi: 10.1146/annurev.micro.112408. 134247

Ogunlaja, O. O., and Parker, W. J. (2015). Assessment of the removal of estrogenicity in biological nutrient removal wastewater treatment processes. Sci. Total Environ. 514, 202-210. doi: 10.1016/j.scitotenv.2015.01.100 
Pandey, A. K., and Sassetti, C. M. (2008). Mycobacterial persistence requires the utilization of host cholesterol. Proc. Natl. Acad. Sci. U.S.A. 105, 4376-4380. doi: 10.1073/pnas.0711159105

Plésiat, P., and Nikaido, H. (1992). Outer membranes of gram-negative bacteria are permeable to steroid probes. Mol. Microbiol. 6, 1323-1333. doi: 10.1111/j.1365-2958.1992.tb00853.x

Qin, D., Ma, C., Hu, A., Zhang, F., Hu, H., and Yu, C. P. (2016). Altererythrobacter estronivorus sp. nov., an estrogen-degrading strain isolated from Yundang Lagoon of Xiamen City in China. Curr. Microbiol. 72, 634-640. doi: 10.1007/s00284-016-0995-y

Qin, D., Ma, C., Lv, M., and Yu, C.-P. (2020). Sphingobium estronivorans sp. nov. and Sphingobium bisphenolivorans sp. nov., isolated from a wastewater treatment plant. Int. J. Syst. Evol. Microbiol. 70, 1822-1829. doi: 10.1099/ijsem.0.003978

Ryan, K. J. (1982). Biochemistry of aromatase : significance to female reproductive physiology. Cancer Res. 42, 3342-3345.

Sambrook, J., and Russell, D. W. (2001). Molecular Cloning: A Laboratory Manual, $3 r d$ Edn. New York, NY, USA: Cold Spring Harbor Laboratory Press.

Schafer, A., Tauch, A., Jager, W., Kalinowski, J., Thierbach, G., and Puhler, A. (1994). Small mobilizable multi-purpose cloning vectors derived from the Escherichia coli plasmids pK18 and pK19: selection of defined deletions in the chromosome of Corynebacterium glutamicum. Gene 145, 69-73. doi: 10.1016/0378-1119(94)90324-7

Schut, G. J., Menon, A. L., and Adams, M. W. W. (2001). 2-Keto acid oxidoreductases from Pyrococcus furiosus and Thermococcus litoralis. Methods Enzymol. 331, 144-158. doi: 10.1016/S0076-6879(01)31053-4

Sharma, S. B., and Signer, E. R. (1990). Temporal and spatial regulation of the symbiotic genes of Rhizobium meliloti in planta revealed by transposon Tn5-gusA. Genes Dev. 4, 344-356. doi: 10.1101/gad.4.3.344

Teles, M., Gravato, C., Pacheco, M., and Santos, M. A. (2004). Juvenile sea bass biotransformation, genotoxic and endocrine responses to $\beta$ naphthoflavone, 4-nonylphenol and $17 \beta$-estradiol individual and combined exposures. Chemosphere 57, 147-158. doi: 10.1016/j.chemosphere.2004. 02.023

Ternes, T. A., Kreckel, P., and Mueller, J. (1999). Behaviour and occurrence of estrogens in municipal sewage treatment plants - II. Aerobic batch experiments with activated sludge. Sci. Total Environ. 225, 91-99. doi: 10.1016/S0048-9697(98)00335-0

Thomas, M. P., and Potter, B. V. L. (2013). The structural biology of oestrogen metabolism. J. Steroid Biochem. Mol. Biol. 137, 27-49. doi: 10.1016/j.jsbmb.2012.12.014

Van Hamme, J. D., Bergstrand, L. H., Mohn, W. W., Cardenas, E., and Holert, J. (2016). Delineation of steroid-degrading microorganisms through comparative genomic analysis. Mbio 7, 1-13. doi: 10.1128/mBio.00865-16
Wang, P., Zheng, D., Peng, W., Wang, Y., Wang, X., Xiong, W., et al. (2019). Characterization of $17 \beta$-hydroxysteroid dehydrogenase and regulators involved in estrogen degradation in Pseudomonas putida SJTE-1. Appl. Microbiol. Biotechnol. 103, 2413-2425. doi: 10.1007/s00253-018-9543-y

Wang, P., Zheng, D., Wang, Y., and Liang, R. (2018). One 3-oxoacyl-(acylcarrier-protein) reductase functions as $17 \beta$-hydroxysteroid dehydrogenase in the estrogen-degrading Pseudomonas putida SJTE-1. Biochem. Biophys. Res. Commun. 505, 910-916. doi: 10.1016/j.bbrc.2018.10.005

Wang, P. H., Chen, Y. L., Wei, S. T. S., Wu, K., Lee, T. H., Wu, T. Y., et al. (2020). Retroconversion of estrogens into androgens by bacteria via a cobalamin-mediated methylation. Proc. Natl. Acad. Sci. U.S.A. 117, 1395-1403. doi: $10.1073 /$ pnas. 1914380117

Wang, P. H., Yu, C. P., Lee, T. H., Lin, C. W., Ismail, W., Wey, S. P., et al. (2014). Anoxic androgen degradation by the denitrifying bacterium Sterolibacterium denitrificans via the 2,3-seco pathway. Appl. Environ. Microbiol. 80, 3442-3452. doi: 10.1128/AEM.03880-13

Wirth, R., Friesenegger, A., and Fiedler, S. (1989). Transformation of various species of gram-negative bacteria belonging to 11 different genera by electroporation. Mol. Gen. Genet. MGG 216, 175-177. doi: 10.1007/BF00332248

Wu, K., Lee, T.-H., Chen, Y.-L., Wang, Y.-S., Wang, P.-H., Yu, C.-P., et al. (2018). Metabolites involved in aerobic degradation of the $\mathrm{A}$ and $\mathrm{B}$ rings of estrogen. Appl. Environ. Microbiol. 85, 1-15. doi: 10.1128/AEM.02223-18

Yu, C.-P., Roh, H., and Chu, K.-H. (2007). 17 $\beta$-Estradiol-degrading bacteria isolated from activated sludge. Environ. Sci. Technol. 41, 486-492. doi: 10.1021/es060923f

Yu, C. P., Deeb, R. A., and Chu, K. H. (2013). Microbial degradation of steroidal estrogens. Chemosphere 91, 1225-1235. doi: 10.1016/j.chemosphere.2013.01.112

Yu, Q., Wang, P., Liu, D., Gao, R., Shao, H., Zhao, H., et al. (2016). Degradation characteristics and metabolic pathway of $17 \beta$-estradiol (E2) by Rhodococcus sp. DS201. Biotechnol. Bioprocess Eng. 21, 804-813. doi: $10.1007 /$ s12257-016-0283-5

Conflict of Interest: The authors declare that the research was conducted in the absence of any commercial or financial relationships that could be construed as a potential conflict of interest.

Copyright (c) 2020 Ibero, Galán, Rivero-Buceta and García. This is an open-access article distributed under the terms of the Creative Commons Attribution License (CC $B Y)$. The use, distribution or reproduction in other forums is permitted, provided the original author(s) and the copyright owner(s) are credited and that the original publication in this journal is cited, in accordance with accepted academic practice. No use, distribution or reproduction is permitted which does not comply with these terms. 